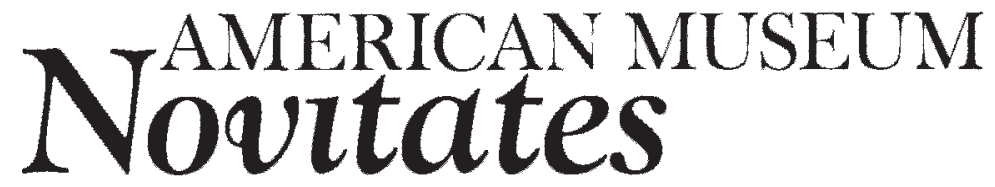

PUBLISHED BY THE AMERICAN MUSEUM OF NATURAL HISTORY CENTRAL PARK WEST AT 79TH STREET, NEW YORK, NY 10024 Number 3570, 31 pp., 7 figures, 2 tables

May 16, 2007

\title{
New Stratigraphic Data from the Erlian Basin: Implications for the Division, Correlation, and Definition of Paleogene Lithological Units in Nei Mongol (Inner Mongolia)
}

\author{
JIN MENG, ${ }^{1}$ YUANQING WANG ${ }^{2}$ XIJUN NI, ${ }^{2}$ K. CHRISTOPHER BEARD, ${ }^{3}$ \\ CHENGKAI SUN, ${ }^{2,4}$ QIAN LI, ${ }^{2}$ XUN JIN, ${ }^{2}$ AND BIN BAI ${ }^{2,5}$
}

\begin{abstract}
Newly measured stratigraphic sections are reported for Paleogene rocks in the NuhetingboerheHuheboerhe (Camp Margetts) area of Nei Mongol (Inner Mongolia), China. The composite sequence in this region is $82.4 \mathrm{~m}$ thick, encompassing three lithological units separated by important depositional hiatuses. In stratigraphic order, these rock units correspond to the Nomogen, Arshanto and Irdin Manha formations. The sequence contains faunas from four Asian land-mammal "ages", the Gashatan, Bumbanian, Arshantan, and Irdinmanhan, which together span the interval from late in the Late Paleocene to early in the Middle Eocene. Comparisons with localities and sections documented since the time of the Central Asiatic Expeditions (CAE) show that the so-called Houldjin gravels of the CAE from this area are mostly Irdin Manha Formation and that the "Irdin Manha beds" of the CAE belong to the Arshanto and/or Nomogen formations. These findings reveal that previous concepts of the Irdin Manha and Arshanto faunas from the Camp Margetts area probably include fossils of different ages, so that the corresponding Asian land-mammal "ages" based on these faunas are problematic and need systematic revision. The Nomogen, Arshanto, and Irdin Manha formations are redefined.
\end{abstract}

\footnotetext{
${ }^{1}$ Division of Paleontology, American Museum of Natural History (jmeng@amnh.org).

${ }^{2}$ Institute of Vertebrate Paleontology and Paleoanthropology, Chinese Academy of Sciences, P.O. Box 643, Beijing 100044, P.R. China.

${ }^{3}$ Section of Vertebrate Paleontology, Carnegie Museum of Natural History, 4400 Forbes Avenue, Pittsburgh, PA 15213.

${ }^{4}$ Section of Natural History, Shandong Provincial Museum, 14 Jing 11th Road, Jinan, Shandong 250014, P.R. China (sunchengk@126.com).

${ }^{5}$ Graduate School of the Chinese Academy of Sciences, Beijing 100039, P.R. China.
} 


\section{INTRODUCTION}

The Mongolian Plateau has been a major source of data for studies of Paleogene vertebrate paleontology and stratigraphy since the pioneering work by the Central Asiatic Expeditions (CAE) of the American Museum of Natural History in the 1920s. Most stratotypes for Paleogene biostratigraphic and chronostratigraphic units in Asia were established on the basis of faunas and sediments from this region. Despite their historic role in providing a basic framework for studying Asian Paleogene faunal succession and intercontinental correlation (Russell and Zhai, 1987; Tong et al., 1995; Meng and McKenna, 1998; Luterbacher et al., 2004), many of these lithostratigraphic and biostratigraphic units were not clearly defined at the time they were proposed. As a result, early Paleogene lithostratigraphic and biostratigraphic units on the Mongolian Plateau continue to be poorly constrained in terms of both superpositional relationships and dating independent of fossils. Correlation of these units remains controversial (Tong et al., 1995; Meng and McKenna, 1998; Beard and Dawson, 1999; Lucas, 2001; Luterbacher et al., 2004; Averianov and Godinot, 2005), which hampers our understanding of Paleogene faunal evolution, intercontinental exchanges, and biotic responses to environmental changes, both regionally and globally.

The Erlian Basin, located on the southern part of the Mongolian Plateau, is particularly pertinent to the Paleogene Nomogen, Arshanto, Irdin Manha, and Houldjin formations and faunas. Since the work of the CAE, when most of these lithological units were named, additional studies of the lithology and faunas of the Erlian Basin have been carried out during the course of the last three decades (Zhou and Qi, 1978; Jiang, 1983; Qi, 1987; Meng, 1990; Meng et al., 1998, 2004; Bowen et al., 2005). During the last few years, significant progress has been made in clarifying the stratigraphy of the Erlian Basin, particularly in the areas of Bayan Ulan and Huheboerhe. Here, we report newly measured sections from the Nuhetingboerhe-Huheboerhe (Camp Margetts) area of the Erlian Basin and compare them with those made since the
CAE, as recorded in field notebooks and published work. We clarify several longstanding problems related to localities, division, and correlation of lithological units, and the stratigraphic occurrences of fossils in the region. We then revisit the definitions of the Irdin Manha, Arshanto, and Nomogen formations. This work represents part of our effort to improve the stratigraphic data associated with fossils collected since the CAE and thus to refine the basis for some Paleogene Asian land-mammal "ages" (LMA) that have been widely used.

\section{RESEARCH HISTORY}

In late April of 1922, the Central Asiatic Expedition (CAE), known as the Third Asiatic Expedition at the time, launched its reconnaissance trip to the Mongolian Plateau from Kalgan, a city now known as Zhangjiakou, China. On August 7, 1922, a paper describing some of the Paleogene strata and fossils encountered during the trip was published (Granger and Berkey, 1922). This paper recognized two Paleogene rock units, the Houldjin and Irdin Manha formations, from the area of Iren Dabasu, today's Erlian salt lake. Near Iren Dabasu was a telegraph station, called Erlian. The Houldjin Formation was located some 5 miles south of the salt lake, from which the first fossil found by the expedition was collected. The Irdin Manha Formation was situated 25 miles (20 miles in Berkey and Morris, 1924; 1927) farther south of the salt lake. The Houldjin beds were then considered to be Miocene or later in age, whereas the Irdin Manha was thought to be Oligocene or Eocene. Berkey and Granger (1923) reiterated their conclusions regarding the Paleogene beds in the Iren Dabasu area. Berkey and Morris (1924) regarded the Houldjin gravel as Lower Oligocene, while they considered the Irdin Manha beds to be Upper or even Middle Eocene. Beneath the Houldjin gravel at Iren Dabasu they observed poorly fossiliferous beds from which the tooth of a small lophiodont was recovered. At Irdin Manha, Berkey and Morris recognized the Arshanto red beds beneath the titanothere rich sandstone and 
noted that "[the] Arshanto may prove to be only the lower Irdin Manha, or it may be separated from the Irdin Manha by a disconformity. The base of these beds has not been seen" (Berkey and Morris, 1924: 119). They tentatively correlated the Arshanto red beds at Irdin Manha with the relatively barren beds at Iren Dabasu. In a more thorough summary of Mongolian geology, based on field investigations made during 1922-23, Berkey and Morris (1927) considered that the barren beds at Iren Dabasu, above the Cretaceous Iren Dabasu Formation and below the Houldjin Formation, probably belonged to the Arshanto Formation. They more formally, but still tentatively, restricted the Irdin Manha Formation at the Irdin Manha locality to the upper gray beds exposed there, referring the lower red beds that had previously been included in the Irdin Manha Formation to the Arshanto Formation (see also Matthew and Granger, 1926).

West of the Irdin Manha area, Granger and Morris made a modest collection of mammal fossils at an escarpment 25 miles southwest of Iren Dabasu in 1923. Seven years later, the CAE team returned to the same area and set up a base named "Camp Margetts". Camp Margetts was used as a geographic waypoint, and several other localities found in 1930 were named in reference to it. Numerous specimens were collected from beds that were thought to be Houldjin and Irdin Manha formations at these localties, but early interpretations of the local stratigraphy proved to be erroneous (see below).

Since the work of the CAE, many investigations have been conducted in the region, including the joint Sino-Soviet paleontological expedition in the late 1950s (Zhou[Chow] and Rozhdestvensky, 1960), fieldwork involving IVPP, the geological mapping team and museum of Nei Mongol in the 1970s (Zhou et al., 1976; Zhou and Qi, 1978; Qi, 1979, 1987; Jiang, 1983), and more recent fieldwork by the present authors and their colleagues (Meng, 1990; Meng et al., 1998, 2004, 2005; Bowen et al., 2005). The most significant progress made in this region during the fieldwork of the 1970s was the discovery of the late Paleocene Nomogen fauna and beds and their equivalents at Bayan Ulan and Subeng (Zhou et al., 1976; Zhou and Qi,
1978; Jiang, 1983; Meng et al., 1998). The Nomogen Formation was described by Zhou et al. (1976), who noted the earlier, informal use of the name by the mapping team from the Geological Survey of Nei Mongol. The "Bayan Ulan Formation" was also proposed based on beds and fauna from the Bayan Ulan locality (Jiang, 1983), but its validity and potential relationship with the Nomogen and Arshanto formations remain questionable (Meng et al., 1998, 2004, 2005; Bowen et al., 2005). Regardless of the controversies surrounding the lithostratigraphy of these upper Paleocene beds, the Nomogen and Bayan Ulan faunas are widely regarded to represent the late Paleocene of Nei Mongol, being correlative with Gashatan faunas across the international boundary in Mongolia. During this time, new terminology was proposed to replace the names for rock units employed by the CAE, but the original names are once again in use. Appendix 1 delineates the various terminologies that have been proposed for lithostratigraphic units in the region.

The most important lithostratigraphic and biostratigraphic advance made in this area in recent years is the discovery of probable Bumbanian beds, characterized by the Gomphos bed, in the Huheboerhe region (Meng et al., 2004; Bowen et al., 2005) and potentially at the Bayan Ulan locality (Meng et al., 2005). As pointed out by Meng et al. (2004), the lithological sequence at Huheboerhe potentially contains strata that are conventionally assigned to the Nomogen, Arshanto, and Irdin Manha formations. However, Meng et al. (2004) chose not to assign the lower beds (beds 1 to 11) at Huheboerhe to any previously named rock unit, although they recognized that the top of these beds is truncated by an erosional surface marking the base of the Irdin Manha Formation. Earlier stratigraphic work in the vicinity of Huheboerhe had been conducted by others. A section from Ulanboerhe was described by Jiang (1983), and another from Huhe Bulak was reported by Qi (1987). These sections do not agree with each other in terms of either lithology or fossil distributions, and their precise geographic locations are unclear. For comparative purposes, we include these sections as appendix 2. 

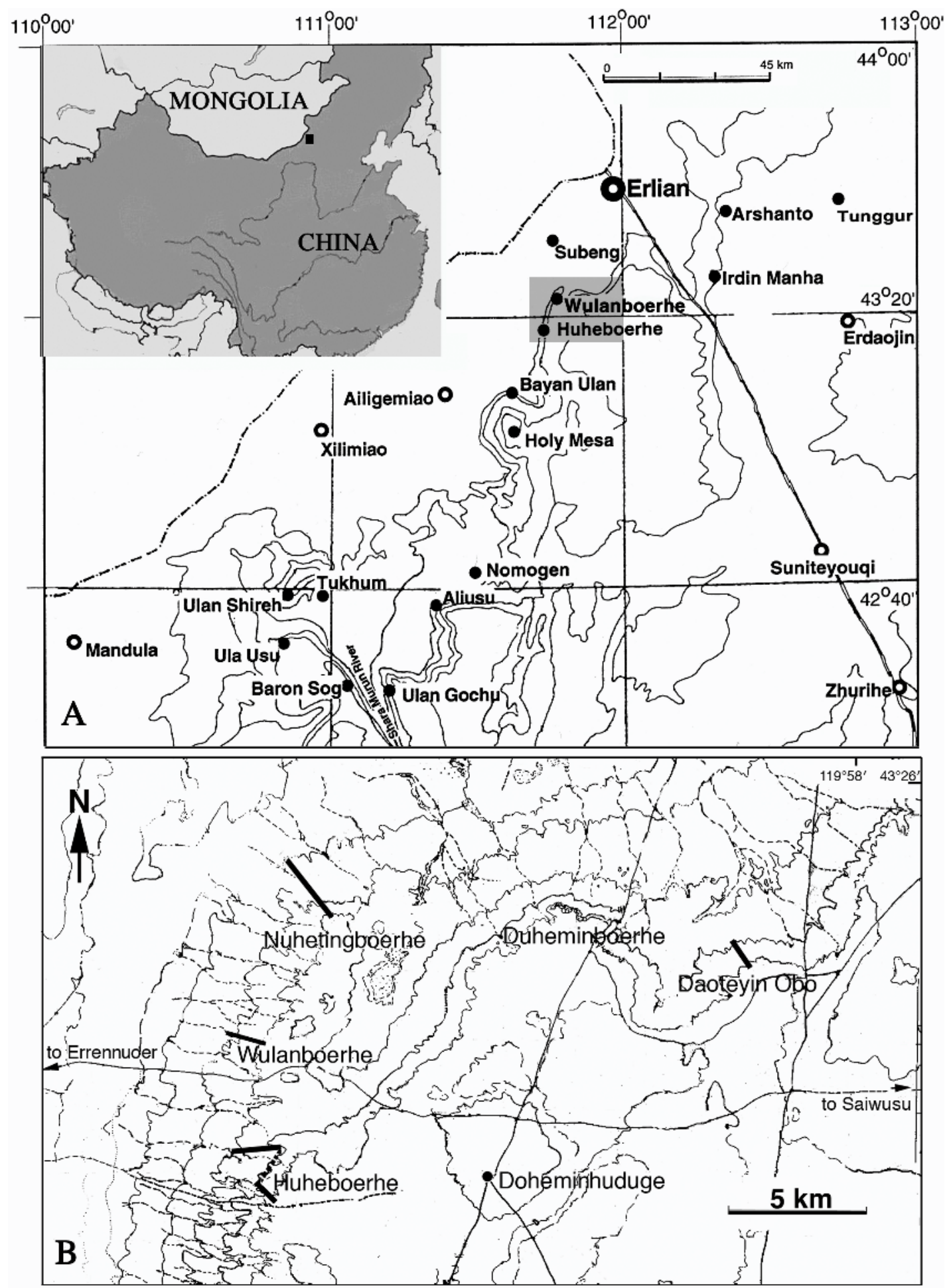

Fig. 1. A. Localities (black dots) of the Erlian Basin, Nei Mongol (Inner Mongolia). The shaded area indicates the location of the Nuhetingboerhe-Huheboerhe area (NHA). B. Topographic map of NHA. The black bars indicate positions of measured sections at the Daoteyin Obo, Nuhetingboerhe, Wulanboerhe (Huheboerhe of Meng et al., 2004), and Huheboerhe. 
This study reports new stratigraphic data obtained during the last two years from the Nuhetingboerhe-Huheboerhe (Camp Margetts) area of Nei Mongol (fig. 1). These data are critical in clarifying several stratigraphic problems that have been in the study of Asian Paleogene since the 1920s.

\section{NEW SECTIONS}

Three newly measured sections and a previous one (Meng et al., 2004) from the Nuhetingboerhe-Huheboerhe area (NHA) are indicated in figure $1 \mathrm{~B}$.

\section{A. Daoteyin Obo Section (fig. 1B) Irdin Manha Formation (upper beds) Endpoint coordinate (top of the section): $43^{\circ} 23.239^{\prime} \mathrm{N} ; 111^{\circ} 55.927^{\prime} \mathrm{E}$}

3) Gray-cemented, cross-bedded sandstone containing conglomerates that are poorly sorted and rounded. Locally, the beds are rusty yellowish and contain fragmentary fossils (mostly large mammals). . . . . . . . . . . . . . . . . Level 19.5-28.5 m (9 m thick)

2) Gray and grayish green sandstone with gravels including nodules from the underlying beds, mostly with a diameter of about $5 \mathrm{~mm}$ and moderately rounded. The top bed is a $30-\mathrm{cm}$ grayish white weathered crust. . . . . . . . . . . . . . Level $16.5-19.5 \mathrm{~m}$ (3 m thick)

\section{—Disconformity (the upper hiatus) -}

\section{Arshanto Formation (middle beds)}

1) Brownish red, with some gray, sandy clays, interbedded with fine sandstone. Weathered surface is loess yellow or dark red. . . . . . . . . . . . . Level 0-16.5 m (16.5 m thick).

Starting point coordinate (base of the section): $43^{\circ} 23.370^{\prime} \mathrm{N}$; $111^{\circ} 55.417^{\prime} \mathrm{E}$.

B. Nuhetingboerhe Section (figs. 1B, 2)

Arshanto Formation (middle beds)

Endpoint coordinate (top of the section): $43^{\circ} 24.045^{\prime} \mathrm{N} ; 111^{\circ} 46.500^{\prime} \mathrm{E}$.

11) Variegated sandstone and sandy mudstone, with conglomeratic lenses in which rounded quartz pebbles are dominant. Thickness of these beds varies considerably. Large crossbedding and uneven erosional surfaces are common. The uppermost beds are brownish yellow lenses of coarse conglomerate with debris that is poorly rounded and sorted. . . . . Level 42.5-50.5 m (8 m thick)

10) A major lithological boundary between the Nomogen and Arshanto formations $\left(43^{\circ}\right.$ $\left.24.087^{\prime} \mathrm{N} ; 111^{\circ} 46.479^{\prime} \mathrm{E}\right)$ is at the level of $37.5 \mathrm{~m}$. The contact surface is uneven. The upper beds start with a 3-cm-thick grayish green clay (fig. 2) above the hiatus. Above the green mudstone lies a $30-\mathrm{cm}$-thick sandstone with cross-bedding and channel fills. The sandstone is primarily gray and light yellow, and contains variegated sandy mudstone. The beds are richly fossiliferous. The Litolophus and Gobiatherium pits known to the south of the cliff should be in the same level. . . . . Level 37.5-42.5 m (5 m thick)

—Disconformity (the lower hiatus; fig. 1) -

Nomogen Formation (lower beds)

9) Reddish sandy mudstone that forms many small isolated hills in front of the main elevated upper part of the cliff; the color of the beds is very distinctive and homogeneous in the NHA. The basal beds of $20-30 \mathrm{~cm}$ contain white calcareous nodules with diameters of 10-30 cm and yielded Gomphos and other fossils. Fossils referable to Pataecops parvus and other fossils were found above the Gomphos bed. The beds become more variegated (brownish red, grayish green) and sandy in upper parts, with weathered surface being earthy brown . . . . . . . . .

. . . . . . L Level 30.5-37.5 m (7 m thick)

8) Brownish red sandy mudstone with grayish green nodules, black stain patches and manganese nodules. The beds become more reddish upward. These beds form the platform at the foot of the elevated hills in this area . . . . Level 24.3-30.5 m (6.2 m thick)

7) Earthy brown and red muddy sandstone, weathering surface light brown, containing calcareous and sandy nodules, some of which are of elongated "fish-dropping" shape, and others are irregular. A 5-10 cm thick, unstable lens with white nodules form the tops of small hills . . . . . . . . . . . .

. . . . . Level 15.7-24.3 m (8.6 m thick)

6) Variegated muddy sandstone and coarse sandstone . . Level 13.0-15.7 m (2.7 m thick) 


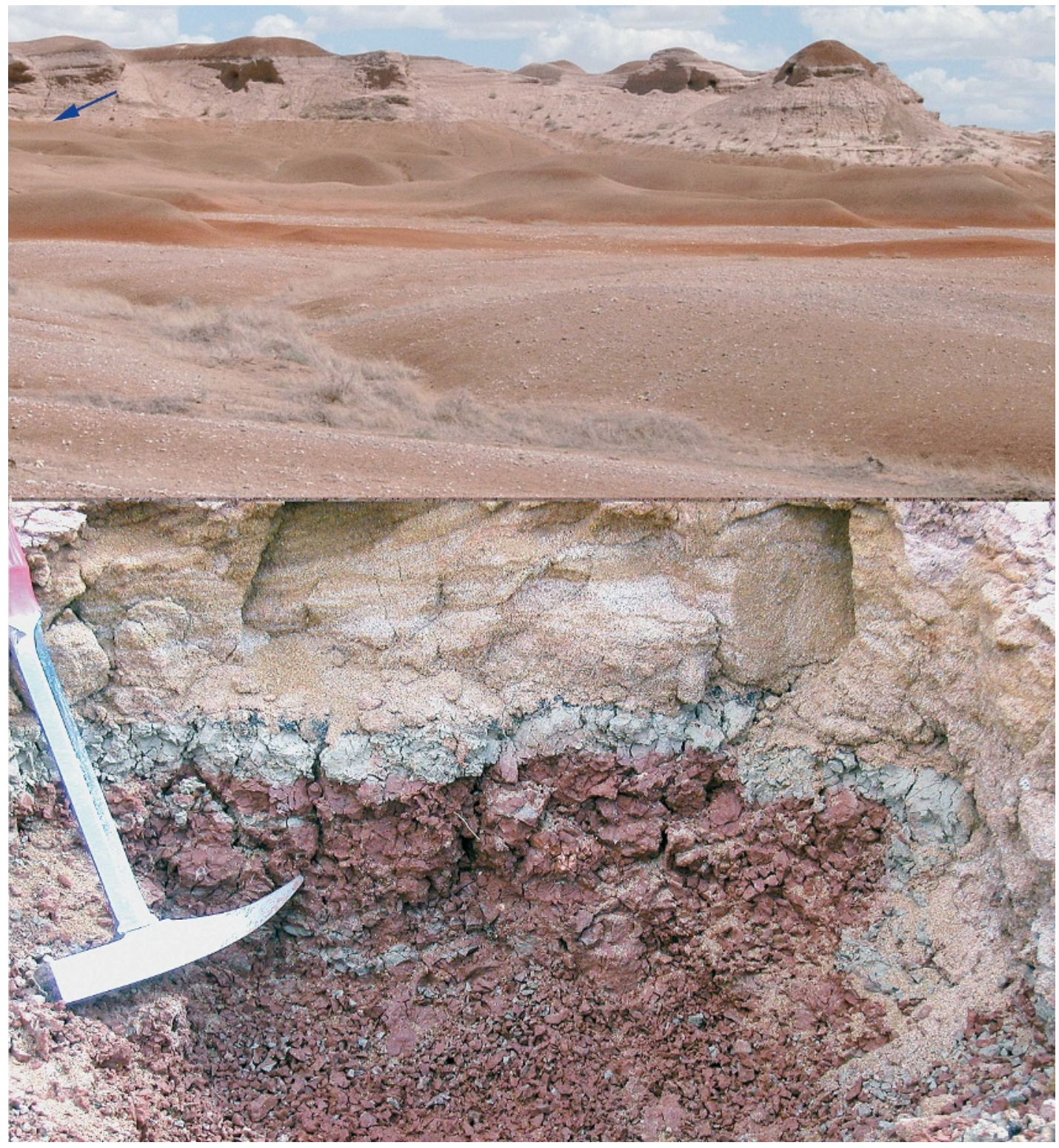

Fig. 2. Above, Paleogene outcrops at the Nuhetingboerhe locality. The arrow points to the lower hiatus between the Nomogen (lower) and Arshanto (upper) formations; Below, Close-up view of the lower hiatus showing the lithology and erosional surface.

5) Brownish red sandy mudstone with nodules $2-$ $20 \mathrm{~mm}$ in diameter, dominated by small ones, which grade into variegated sandy mudstone and fine sandstone with pebbles .......

. . . . . . Level 10.2-13.0 m (2.8 m thick)

4) Grayish white and green fine sandstone, with horizontal bedding. The lower beds contain white calcareous nodules ranging from 5$40 \mathrm{~mm}$ in diameter and many segments of petrified woods. The beds become sandy mudstone and more variegated (grayish brown, green) upward . . . . . . . . .

. . . . . . Level 8.5-10.2 m (1.7 m thick).

3) Variegated (earthy yellow, light reddish) sandy mudstone, with nodules of mudstone. Petrified wood having a diameter of up to $20 \mathrm{~mm}$ is present. The mudstone is structureless, with irregular cracks after weathering. 
Fossils typical of Late Paleocene Bayan Ulan fauna, such as Lambdopsalis, Prionessus, and Palaeostylops, are found in the beds . . . . . ......... Level 5.1-8.5 m (3.4 m thick)

2) Brownish red muddy sandstone, soft and containing small nodules, no bedding structure, interbedded with yellowish green sandstone lens and siltstone with fine bedding; weathered surface coffee-colored........

. . . . . . . Level 2.2-5.1 m (2.9 m thick).

1) Pale grayish green sandy clay, structureless, containing small debris of rock, capped by a layer of $5-10 \mathrm{~cm}$ thick hard sandstone ...... Level 0-2.2 m (2.2 m thick)

Starting point coordinate (base of the section covered): $43^{\circ} 24.803^{\prime} \mathrm{N} ; 111^{\circ} 45.579^{\prime} \mathrm{E}$.

C. Huheboerhe Section (figs. 1B, 3, 4)

Irdin Manha Formation (upper beds)

Endpoint coordinate (top of the section): $43^{\circ} 19.793^{\prime} \mathrm{N} ; 111^{\circ} 45.409^{\prime} \mathrm{E}$

11) Grayish white sandy conglomerates with poorly sorted and rounded, dark-colored debris. Also fossiliferous, including bronthotheres and other perissodactyls. On the top of the mesa, or the Gobi plain, are sandstone and conglomerates consisting of particles of quartz that are better sorted and rounded . . Level 48.2-52.4 m (4.2 m thick)

10) The boundary between the middle beds (Arshanto Formation) and the upper beds (Irdin Manha Formation; fig. 4) is at the level of $42.6 \mathrm{~m}$ level. The contact surface is distinctively uneven. Gray muddy sandstone and coarse sandstone containing lumps of reddish mudstone from underlying beds and some white nodules; thin-layered yellowish green sandy mudstone and sandstone, interbedded with lenses of conglomerate and reddish sandy mudstone; richly fossiliferous, including petrified wood and mammals (rodents, lagomorphs, artiodactyls, primates hyaenodontid, and perissodactyls are currently identified) . . . . . . . . . . . $\ldots \ldots$ Level $42.6-48.2 \mathrm{~m}$ (5.6 m thick)

—Disconformity (the upper hiatus; fig. 4) _

\section{Arshanto Formation (middle beds)}

9) Variegated (earthy or reddish) sandy mudstone .... Level 37.7-42.6 m (4.9 m thick)
8) Grayish green, variegated sandy siltstone and fine sandstone, containing nodules of mudstone from underlying beds and perissodactyl fossils . . . . . . . . . . . . . Level $30.0-37.7 \mathrm{~m}$ (7.7 m thick)

7) Light brownish siltstone or mudstone, also with black stain on the surface. The contact surface with the underlying beds is uneven, but does not look like a significant depositional hiatus. Some levels are more sandy and the top $30 \mathrm{~cm}$ of the beds are more reddish. Many fossil fragments, mostly from small mammals . . . . . . . . . . . . . . . . . . . . Level 27.9-30.0 m (2.1 m thick)

6) Earthy, muddy siltstone interbedded with sandy lenses and fossiliferous . . . . . . . . . . . . . . . Level 19.8-27.9 m (8.1 m thick)

5) Reddish sandy mudstone, with black stain; nodules and fossil fragments in transitional beds. Fossils of hyaenodontid and numerious perrisodactyls were found in this level. A quarry site that yielded many rodent specimens was located at level of $19 \mathrm{~m}$ of the section ..............

. . . . . . Level 17.1-19.8 m (2.7 m thick)

4) Fine sandstone, primarily grayish green siltstone, with bands of mudstone. Some bone fragments and petrified wood, usually from the lower grayish green beds. . . . . . . . . . . . . . . Level 12.7-17.1 m (4.4 m thick)

3) The contact surface is uneven, representing a depositional hiatus (fig. 3). Beds above the boundary are fluvial sandstone, coarse sandstone with small debris and purplish beds with cross-bedding, similar to those of the Litolophus and Gobiatherium pits at the Wulanboerhe section. Fossils of Metacoryphodon and perissodactyls . . . . . . . . . . . . . . . Level 7.4-12.7 m (5.3 m thick)

-Disconformity (the lower hiatus; fig. 3) -

Nomogen Formation (lower beds)

2) Fine sandy mudstone, with increasing grayish green color and black manganese nodules or irregular patches of black stains . . . . . . . . . . . . . . Level 2.6-7.4 m (4.8 m thick)

1) Variegated (brownish red, grayish green, with black stain) siltstone and sandy mudstone. These beds contain white nodules and fossils of Gomphos, and are similar to and correlative with those that yield Gomphos in the Nuhetingboerhe section and in the section of Meng et al. (2004) . . . . . . . . . . . . . . . $\ldots \ldots \ldots$ Level $0-2.6 \mathrm{~m}$ (2.6 m thick) 


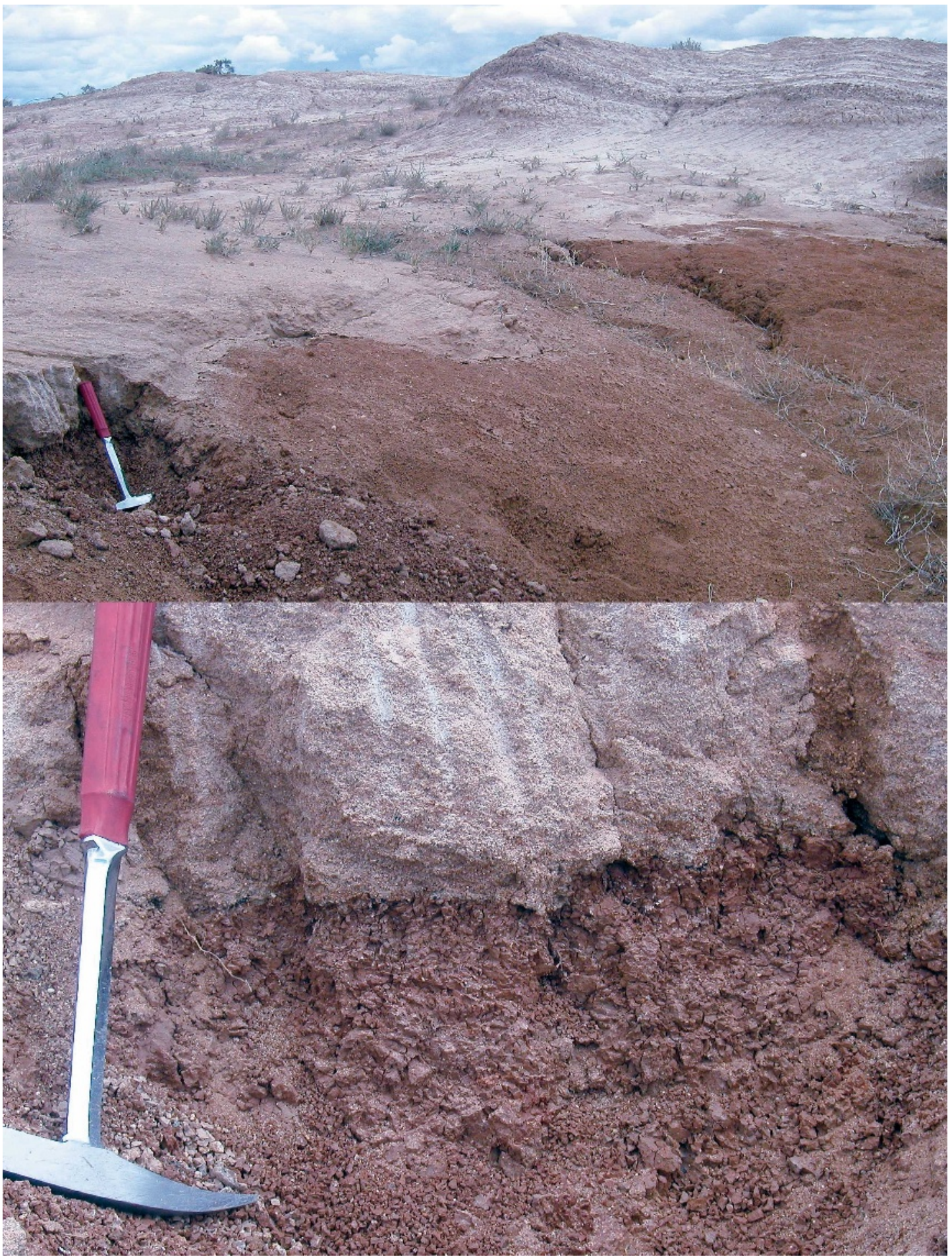

Fig. 3. Above, Beds at the transition of the Nomogen (lower) and Arshanto (upper) at the Huheboerhe locality. Below, Close-up view of the lower hiatus showing the lithology and erosional surface between the Nomogen and Arshanto fomarions. 


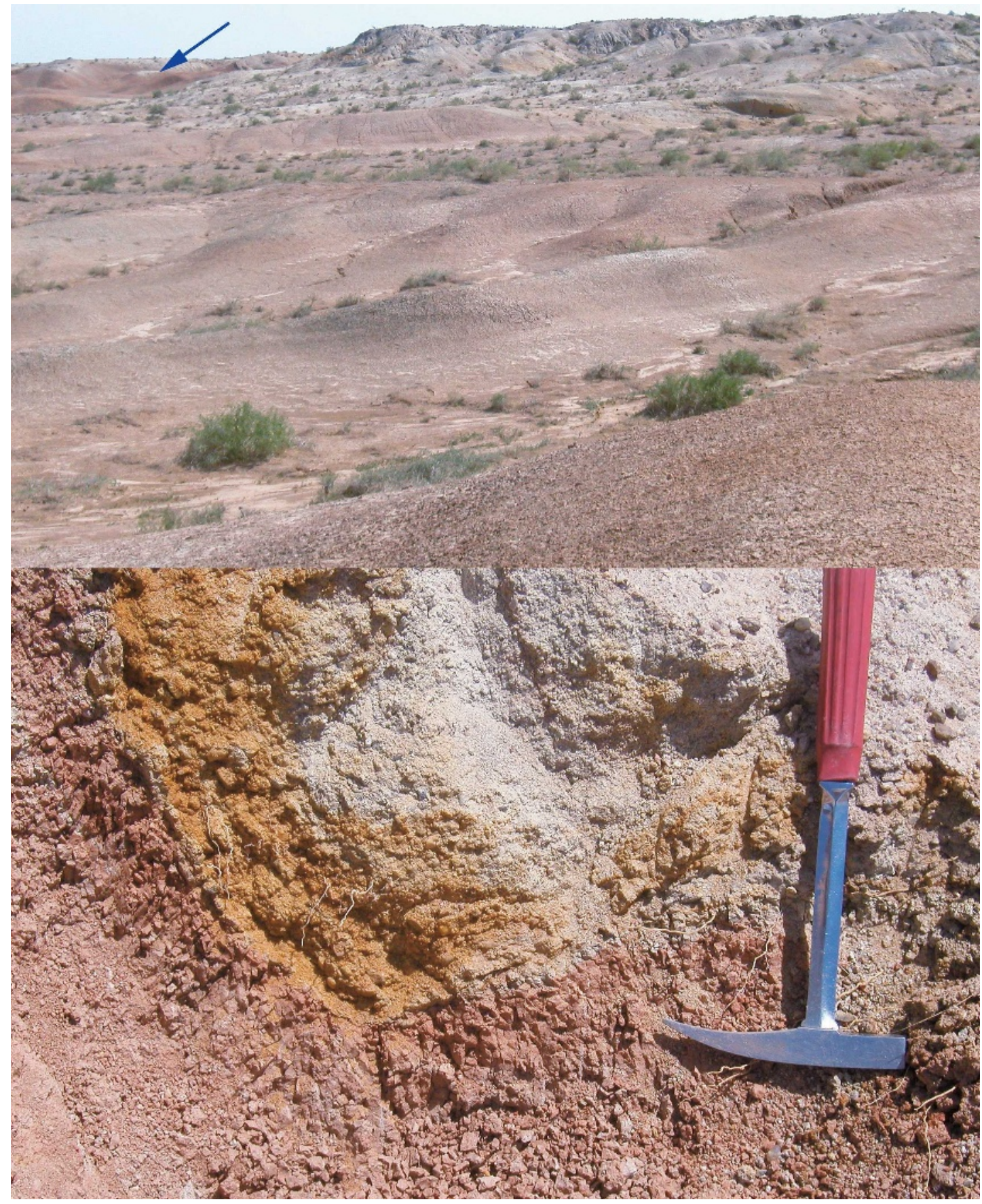

Fig. 4. Above, The Arshanto Formaiton (middle beds) and Irdin Manha Formation (upper beds) at the Nuhetingboerhe locality; the arrow points to the upper hiatus between the two formatitons. Below, Close-up view of the upper hiatus showing the lithology and erosional surface. 
Starting point coordinate (base of the section covered): $43^{\circ} 20.330^{\prime} \mathrm{N} ; 111^{\circ} 44.807^{\prime} \mathrm{E}$.

\section{LOCALITIES}

We refer to the area depicted in figure 1 as the Nuhetingboerhe-Huheboerhe area (NHA), which corresponds roughly to the Camp Margetts (CM) area of the CAE. On the topographic map each locality name, such as Huheboerhe, does not refer specifically to a landmark or a clearly delimited area, but designates a general segment of the escarpment. These names have changed over time. Many local names used in figure 1, which is based on topographic maps published in the 1960s, have been altered on topographic maps published in the 1990s. Because several local names on the topographic maps published in the 1960s have been used in research publications, we choose to use those names in this study.

The sections measured at Daoteyin Obo, Nuhetingboerhe, and Huheboerhe in the 2005 field season are indicated in figure 1. The NHA has been visited by several field parties since 1923, but locality data remain unclear (Meng, 1990; Meng et al., 1998). Here we intend to relocate these localities based on previous fieldnotes, publications, and our field observations.

The location of Camp Margetts as a field base is close to the 1923 site, which is about $40 \mathrm{~km}$ (25 miles) southwest of the Erlian salt lake (Iren Dabasu) and probably on the edge of the escarpment where the site called Duheminboerhe is located on the topographic map published in the 1960s (see Meng, 1990; fig. 1). Other CAE sites include, ranging from east to west: 5 miles east (also called the Overnight Camp), 2 miles east, $1 / 2$ mile west, 1 mile west, $1 \frac{1 / 2}{2}$ miles west, 6 miles west, 7 miles southwest $\left(235^{\circ}\right)$, and 10 miles southwest of CM. Fossils collected from these sites by the CAE team are listed in appendix 3 . Based on their distance and direction, the Overnight Camp was probably on the escarpment called Daoteyin Obo, the site 6 miles west of CM was probably near today's Nuhetingboerhe escarpment, the 7 miles southwest $\left(235^{\circ}\right)$ site was most likely near Wulanboerhe, and the 10 miles southwest site should have been around today's Huheboerhe (fig. 1).

Radinsky (1964) treated localities 7 miles west and 7 miles southwest $\left(235^{\circ}\right)$ of $\mathrm{CM}$ as if they were two different sites, which appears not to be the case. According to Granger (1930: 38), fossils were collected "from an exposure about 7 miles, $235^{\circ}$, from Camp Margetts." In the successive pages of his fieldnotes, he recorded all fossils from this site as being "7 mi. w. Camp Margetts." Thus, we infer that only one site occurs in this range, 7 miles southwest $\left(235^{\circ}\right)$ of $\mathrm{CM}$.

Not only do the distances from Camp Margetts correspond for these sites, but also Granger's (1930) sketch sections for his 7 miles southwest $\left(235^{\circ}\right)$ and 10 miles southwest sites are also similar in lithology, and even topography, to what we observed in exposures of the NHA, although assignments of rock units are quite different (see below). Moreover, fossils help to correlate these localities. For instance, fossils of Litolophus gobiensis, a chalicothere, were recorded only from 6 miles west of $\mathrm{CM}$ in the CAE collections. Today, notable concentrations of Litolophus are found in one area on the Nuhetingboerhe escarpment. The geographic distribution of chalicotheres supports our relocation of the relevant sites.

Three sections have been published previously from the NHA, including the Wulanboerhe section (Jiang, 1983), Huhe Bulak section (Qi, 1987) and Huheboerhe section (Meng et al., 2004). The sections reported by Jiang and Qi have no coordinates (see appendix 2) and cannot be precisely relocated. However, from the positions of the sections marked on the location maps and lithology and fossils of the sequences described in the original reports, it is probable that the Wulanboerhe section of Jiang is from Wulanboerhe as indicated in figure 1 and that the Huhe Bulak section of Qi is likely on the Huheboerhe escarpment. The Huheboerhe section of Meng et al. (2004; fig. 1), for which precise geographic coordinates are available, is actually closer to Wulanboerhe than to Huheboerhe, and should therefore be close to the section reported by Jiang and referred to as Wulanboerhe section. 


\section{STRATIGRAPHY OF NHA}

LithoSTRATIGRAPHY: Lithostratigraphy in the NHA has proved to be problematic since the work of CAE because of several factors. First, early workers did not provide clear definitions of the named formations. For instance, the lower limits of the Arshanto and Houldjin formations and the upper limit of the Irdin Manha Formation were unknown. Similarly, the lower and upper limites of the Nomogen Formation are both unknown at its type locality. These ambiguities have left room for later investigators to draw boundaries or to divide rock sequences using different criteria. Second, as is typical for continental sediments, the lithology of rock units of the same age can vary considerably as beds are traced laterally. Because of this fact, premature proposals of additional lithological units were made in the 1970s, complicating stratigraphic correlations in the region (appendices 1 and 2). Finally, as depositional cycles repeated themselves during geological time, sediments of different ages often display similar lithology, further complicating efforts to recognize and correlate rock units.

Although lithological sequences have been described from several transects of the NHA (Granger, 1930; Jiang, 1983; Qi, 1987; Meng et al., 2004), we know for the first time that the sediments in the area differ in their lithologies and significantly in their ages (fig. 5). Escarpments along the WulanboerheNuhetingboerhe are formed primarily by beds that produced the Late Paleocene fauna and Early Eocene Gomphos fauna. These beds are capped by a relatively thin sequence of fluvial sediments that produced the chalicothere fauna. In contrast, the Huheboerhe escarpment is dominated by younger strata, where the Gomphos bed is the basal unit, and the younger beds form the main body of the cliff. Exposures along the Daoteyin OboDuheminboerhe escarpments are thin and are best correlated to the top part of the Huheboerhe section. From the topographic map one can also see that the sections at Daoteyin Obo and Huheboerhe are relatively higher in altitude than those from Nuhetinboerhe and Wulanboerhe. Using the Gomphos bed as a marker, our correlation of these beds is shown in fig. 5 .
Two major depositional hiatuses exist in the sequences of NHA, referred to as the lower and upper hiatus, respectively (fig. 5). These hiatuses are good boundaries to delimit formations and to correlate beds of the region. The intervals of time that are represented by these hiatuses are currently unclear. The lower hiatus occurs at the $37.5 \mathrm{~m}$ level in the Nuhetingboerhe section and can be traced laterally to the hiatus between beds 11 and 12 in the section reported by Meng et al. (2004) and its equivalent between beds 2 and 3 (level $7.4 \mathrm{~m}$ ) in the Huheboerhe section (figs. 2, 3, 5). The upper hiatus lies at the $42.6 \mathrm{~m}$ level of the Huheboerhe section, between beds 9 and 10 and between beds 1 and 2 in the Daoteyin Obo section (figs. 4, 5). Although the Daoteyin Obo section is short, we are able to correlate it with the upper part of the Huheboerhe section on the basis of similar lithology, altitude (as indicated by GPS elevation readings and positions on the topographic map; fig. 1), and fossil contents.

The two hiatuses separate the NHA sequence into three packages, referred to as the lower, middle, and upper beds (fig. 5). The lower beds in the Nuhetingboerhe section are at least $37.5 \mathrm{~m}$ thick, with the base being covered. Taken as a whole, the lower beds are dominated by gray mudstones and fine sandstones. Their upper part has more reddish sandy clays. In the section reported by Meng et al. (2004), the lower beds are largely comparable to those of the Nuhetingboerhe section, but the strata that produce multituberculates are currently unknown in the Wulanboerhe section. Meng et al. (2004) noted the lower hiatus and considered that this erosional surface represents the most distinctive and regionally traceable stratigraphic datum for this part of the early Paleogene sediments in the Erlian Basin. However, those authors chose not to assign beds (beds 1 to 11 ) below the hiatus to any named rock unit, but recognized that the upper bed (bed 12 of Meng et al., 2004) above the hiatus is typical of the Irdin Manha Formation. They recognized no significant sedimentological hiatus in the section below the erosional surface, a view contrary to previous studies in this region (Jiang, 1983; Qi, 1987). Meng et al. (2004), however, noted 


\section{Daoteyin Obo}

\section{Huheboerhe}

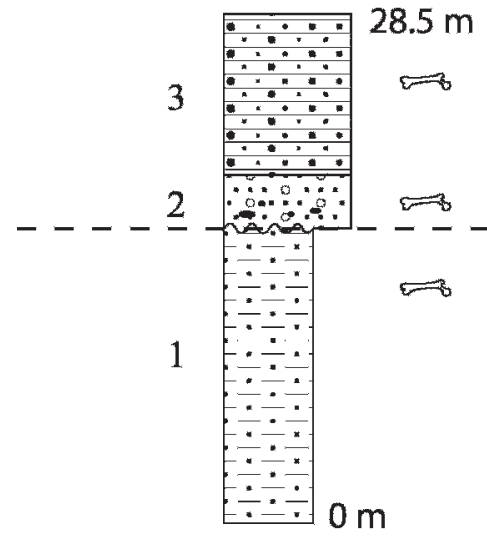

Arshanto Formation

Nomogen Formation
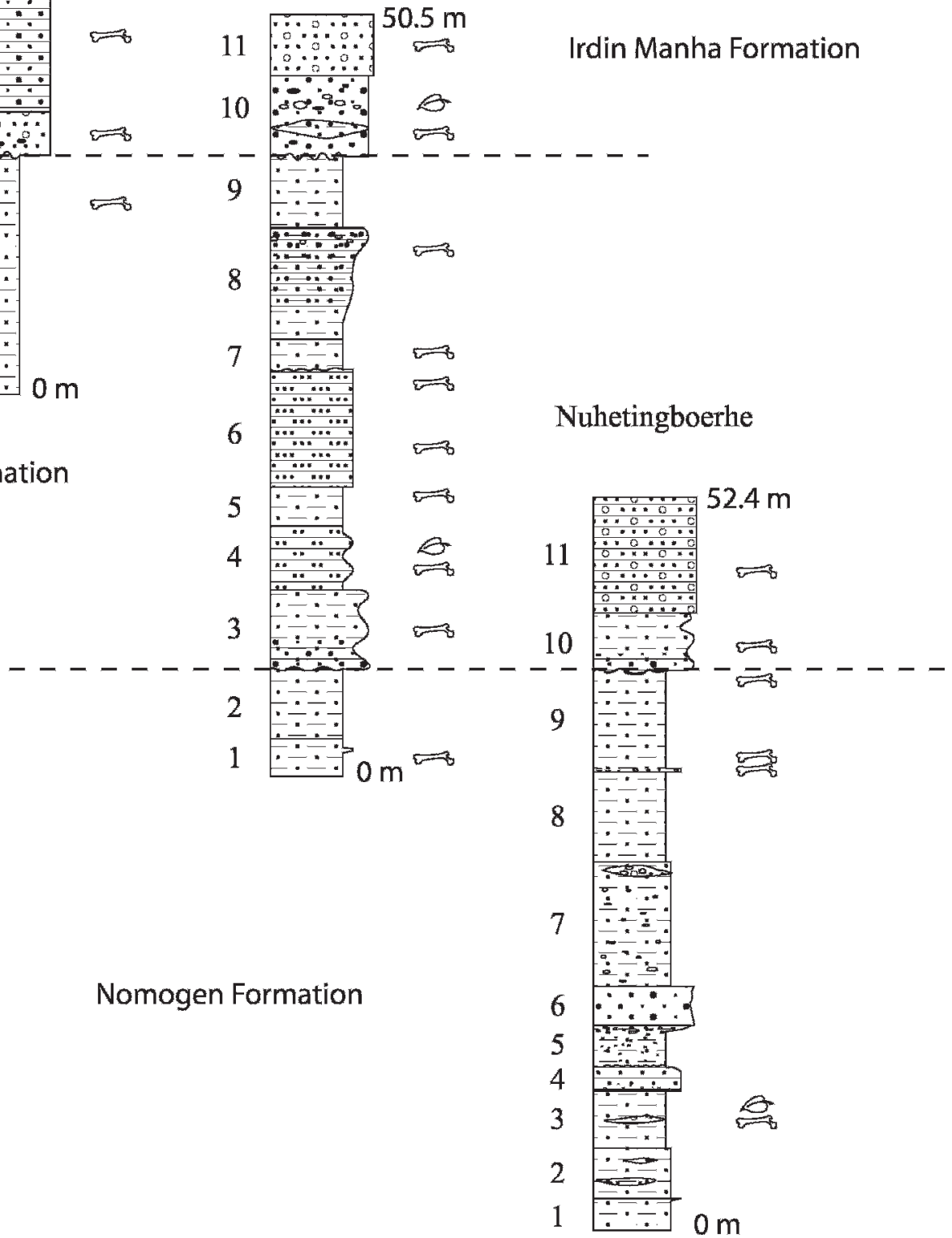

Fig. 5. Stratigraphic correlations of the Nuhetingboerhe-Huheboerhe area (NHA). See Fig. 1B for the locations of the sections.

a significant color transition between beds 10 and 11 in their section, and a large number of white calcareous nodules in the bottom of bed 11, and considered these as indicative of paleosol formed under different conditions from those during the deposition of the underlying beds. They also thought that the presumably Bumbanian fauna, dominated by Gomphos, occurred in the upper part of bed 10. 
Our field observations at Nuhetingboerhe duplicate those made by Meng et al. (2004), except that the Gomphos fauna probably comes directly from the red beds that contain the white nodules. On the Nuhetingboerhe and Wulanboerhe escarpments, only the lower part of the middle beds, primarily channel fills and cross-bedded sandstone, are preserved (figs. 2, 5).

At Huheboerhe, the Gomphos bed is basal and the lower hiatus is at the $7.4 \mathrm{~m}$ level in the measured section (figs. 3, 5); only the upper part of the lower beds is exposed. The main body of the cliff is formed by the middle beds, which are $35.2 \mathrm{~m}$ thick and bracketed by the two hiatuses. The middle beds are a set of sediments that start with coarse fluvial sandstone and channel fills and grade upward into sandstone and clays, probably representing a sedimentological cycle. Relatively minor variations of sandstones and mudstone are common within the package. Colors of sediments vary considerably from place to place in the middle beds. Because the erosional surfaces of the two hiatuses are uneven, the thickness of the middle beds also varies at different transects of the escarpment.

The upper beds are exposed on the top of the Huheboerhe escarpment (figs. 4, 5) and at Daoteyin Obo. Because the upper hiatus and the eroded top surface of the section are both uneven, the thickness of the upper beds varies considerably at various transects of the escarpment. They are $9.8 \mathrm{~m}$ thick at the transect corresponding to the measured section. These beds are dominated by coarse gray fluvial sandstones and channel fills, and are somewhat similar to the lithology of the basal portion of the middle beds. In the Daoteyin Obo section, only the upper part of the middle beds and some of the upper beds are exposed.

BIOSTRATIGRAPHY: Because both the lower and upper hiatus and the beds containing them compare favorably with the lithological transition seen at the type section for Arshanto-Irdin Manha, it is not straightforward to correlate these strata solely on lithology. In this regard, fossils can be very helpful, given that many fossils have been collected from the type Irdin Manha beds and from the NHA. For instance, Lophialetes expeditus has been recognized as characteristic of the type Irdin Manha beds (Radinsky, 1964). Finding this species, and other fossils, in beds of the NHA would be useful for stratigraphic correlation. We realize that because a large number of fossils have been collected from the NHA since 1930 and yet profound stratigraphic errors have been embedded in the data asscociated with these fossils, considerable effort must be made to clarify the biostratigraphic issues of this region. Here we present a preliminary account of the biostratigraphy of the region based on old collections and those we have made in the last two years, although most of our new fossils have not been studied in detail.

1) The basal beds at the Nuhetingboerhe section have produced the Late Paleocene fauna characterized by Lambdopsalis, Palaeostylops and Prioenssus (fig. 5). These taxa commonly occur in Late Paleocene faunas from the Nomogen, Bayan Ulan and Subeng localities in Nei Mongol, as well as in Gashatan faunas in Mongolia. There is no doubt that the basal beds of the NHA sequence extend back to the Late Paleocene.

2) The Early Eocene fauna, here termed as the Gomphos fauna, is characterized by the presence of Gomphos elkema and other mammals and is found in the Nuhetingboerhe and Huheboerhe sections and in the one reported by Meng et al. (2004). Gomphos elkema was considered the primary evidence for an Early Eocene age for the beds because this taxon was previously known from the Early Eocene Bumban beds of Mongolia (Dashzeveg, 1988; Asher et al., 2005). In addition, ctenodactyloid rodents similar to those of the Bumbanian species (Dashzeveg, 1990) and a euprimate closely similar to "Teilhardina" brandti from the earliest Eocene Wa0 of Wyoming (Gingerich, 1993) was also known from the Gomphos bed (Ni et al., in press). A lower jaw of Prodinoceras, a typical Late Paleocene taxon, has been found between the Lambdopsalis bed and the Gomphos bed (Bowen et al., 2005), which constrains the stratigraphic extent of the Late Paleocene beds in the sequence.

3) Immediately above the Gomphos bed is an assemblage that includes fossils referable to Pataecops parvus and other mammals. Still higher in position but below the lower hiatus, 
a lower jaw referred to as Uintatherium $\mathrm{sp}$. (Bai, 2006) was found.

Pataecops parvus (Radinsky, 1965) Radinsky, 1966, was known from the Kholobolchi Formation (also known as Kholboldji suite, Dashzeveg, 1991; Kholoboldzhi-Nur Svita, Russell and Zhai, 1987), Menkhen Teg, Mongolia. The age of the Kholobolchi fauna was considered to be Middle Eocene (Russell and Zhai, 1987; Dashzeveg, 1991). More recent workers regard the age of the Kholobolchi fauna to be Arshantan (Dashzeveg and Hooker, 1997; Lucas, 2001). Dashzeveg and Hooker (1997: 136) suggested that the Arshantan "predates the Irdinmanhan and belongs to the earliest middle or latest early Eocene", whereas Lucas (2001) considered the Arshantan land mammal age to be older than the North American middle Bridgerian. Lucas and Emry (2001) regarded the Irdinmanhan and Arshantan ages as collectively correlative with the Bridgerian, but Luterbacher et al. (2004) correlate the Arshantan with the entire Bridgerian and the Irdinmanhan with the Uintan. Pataecops munutissimus from the lower Alay beds (latest Early Eocene) at the Andarak 2 locality in Kyrgyzstan is smaller than $P$. parvus but is not necessarily more primitive than the Mongolian species (Averianov and Godinot, 2005). Following the definition of the Arshantan and Irdinmanhan by Lucas (2001), Averianov and Godinot (2005) considered the Andarak fauna to be Irdinmanhan in age. However, because the Andarak mammals are found within a marine section that yields a large Selachian fauna, Averianov and Godinot $(1998,2005)$ argued that the Andarak fauna, and thus the Irdinmanhan, be considered belonging to the latest Early Eocene (late Ypresian, but see Lucas and Emry, 2001).

If the correlation of the Gomphos fauna at NHA with the Bumbanian fauna is correct (Meng et al., 2004), the occurrence of Pataecops parvus immediately above the Gomphos fauna supports an age for the Arshantan earlier than the Middle Eocene, a notion more concordant with the age estimate of the Arshantan proposed by Dashzeveg and Hooker (1997), or even earlier. Whether the Irdinmanhan age will extend into the latest Early Eocene, as Averianov and Godinot (2005) suggested, remains questionable. Part of the uncertainty may be rooted in the mixed faunas from the Arshanto and Irdin Manha formations, as will be further discussed below.

4) There are several fossiliferous levels within the middle beds, and the fossil assemblages are distinctive from those below the hiatus. Large mammals including Metacoryphodon, Gobiatherium, and Litolophus have been found in the basal fluvial beds above the lower hiatus. Although these fossils may differ modestly in their stratigraphic occurrences, they can be lumped into one assemblage. The beds yielding the Metacoryphodon are immediately above the lower hiatus in the Huheboerhe section and represent the lowest part of the middle beds. Similar specimens collected previously from this area have been named Metacoryphodon luminis (Qi, 1987, IVPP 5697), but Lucas (1998) regarded this species as a symnonym of Eudinoceras mongoliensis, which is one of the taxa that marks the beginning of the Arshantan land-mammal age according to Lucas (2001).

5) The beds that preserved a concentration of Litolophus, a chalicothere, also generated numerous specimens of rodents, lagomorphs, and other mammals. Litolophus gobiensis (Colbert, 1934; Radinsky, 1964b) was universally considered an Irdinmanhan taxon $(\mathrm{Li}$ and Ting, 1983; Russell and Zhai, 1987; Lucas, 2001), although Radinsky (1964a) was puzzled by its peculiar occurrence in Irdin Manha beds. We will show below that Litolophus, collected from the locality 6 miles west of Camp Margetts, was from the Arshanto Formation, not from the Irdin Manha Formation.

A primitive lagomorph has been described from the Litolophus assemblage (Li et al., in press). The new lagomorph is similar to, but more primitive than, Aktashmys montealbus (Averianov, 1994) from beds dated as terminal Early Eocene at the Andarak 2 locality, Kyrgystan (Averianov and Lopatin, 2005). It is also more primitive than other Eocene forms, such as Lushilagus and Strenulagus, of Irdinmanhan age. In addition to a diverse group of ctenodactyloid rodents, at least two new miniscule rodents have been recognized 
from the Litolophus assemblage (unpublished data). One of them is a myodont that is morphologically more primitive than Elymys complexus from the early Middle Eocene (early Bridgerian) North American (Emry and Korth, 1989) and Middle Eocene Asian myodonts such as Aksyiromys dabs (Shevyreva, 1984; Emry et al., 1998), Primisminthus, and Banyuesminthus (Tong, 1997). The other represents a group unknown previously, which is similar to alagomyids in several dental aspects but has upper cheek teeth being considerably narrower (Meng et al., in press). These findings suggest that the beds yielding the fauna are older than Middle Eocene.

6) Beds 5 and 6 in our Huheboerhe section, which are higher than the Litolophus beds, produced numerous fossils of hyaenodontids, insectivores, lagomorphs, rodents, and perrisodactyls. Preliminary identifications show that some rodents are referable to Advenimus and/or Tamquammys, and the most abundant perissodactyls are referable to Schlosseria magister. Advenimus burkei was named based on specimens from the site 7 miles southwest $\left(235^{\circ}\right)$ of CM (Dawson, 1964; appendix 3). Schlosseria magister (Matthew and Granger, 1926) is a perissodactyl typical of the Arshanto fauna. The type specimen (AMNH 20241; field number 172) was collected from the Arshanto Formation in the northeastern basin of Irdin Manha, about 7 miles north of the telegraph line and were the first and only fossils from the Arshanto Formation at this site. Radinsky (1964a) also noted that Schlosseria magister came from the Arshanto beds. In a later study, Radinsky (1965: 197) wrote: "In the Irdin Manha area the beds containing Schlosseria underlie those with Lophialetes, but in the Camp Margetts area both genera are recorded as coming from the same horizon." This coexistence was endorsed by Qi (1987), and Schlosseria was included in the composite Irdinmanhan fauna (Lucas, 2001). However, the occurrence of Schlosseria, at least in the Camp Margetts area, is problematic as a result of the incorrect division and correlation of beds in the region (see below). Tong et al. (1995) thought Teilhardia, another perissodactyl, was from the type Arshanto beds, which is untrue. The type specimen of Teilhardia was from the lower red beds at the Shara Murun Formation at Ula Usu (Matthew and Granger, 1926).

7) The upper beds are also fossiliferous. We have collected several mammals, including rodents, lagomorphs, perrisodactyls, and other forms. Brontotheres are common in the Middle Eocene in North America and Asia and are particularly abundant in the Irdinmanhan age (Mihlbachler, in press). Some of the perrisodactyls from the upper beds are referable to Lophialetes and Rhodopagus, both being typical Irdin Manha taxa.

It is clear that the sequence of the NHA contains faunas from four Asian LMAs, Gashatan, Bumbanian, Arshantan and Irdinmanhan, and that it spans the interval of Late Paleocene to Middle Eocene. Based on both lithology and fossils, we think the upper hiatus correlates best with the Arshanto-Irdin Manha boundary, the fluvial sediments above the upper hiatus (the upper beds) to the Irdin Manha Formation, part of the middle beds below the upper hiatus to the conventional Arshanto Formation, and the lower beds yielding the Late Paleocene and Early Eocene faunas to the Nomogen Formation. The composite sequence has a total thickness of $82.4 \mathrm{~m}$ (fig. 5).

\section{COMPARISON OF SECTIONS}

The CAE sections: Four sections from the Camp Margetts area were recorded in the field notebooks of the CAE team. The one sketched by Morris (1923) at Camp Margetts described the lithology but did not assign strata to any named unit. The other three were made at Camp Margetts and 7 miles southwest $\left(235^{\circ}\right)$ and 10 miles southwest of CM by Granger (1930; figs. 6, 7). In Granger's sketched sections the lower red clays were considered to be "Irdin Manha beds" whereas the upper sandstone "Houldjin beds". Recognition of these lithological units had changed with increased stratigraphic knowledge of the region during that period of time. As noted by Radinsky (1964), for instance, specimens collected in the area in 1923 (AMNH 20161, the type of Desmatotherium fissuin, and AMNH 20136, a large achaeno- 


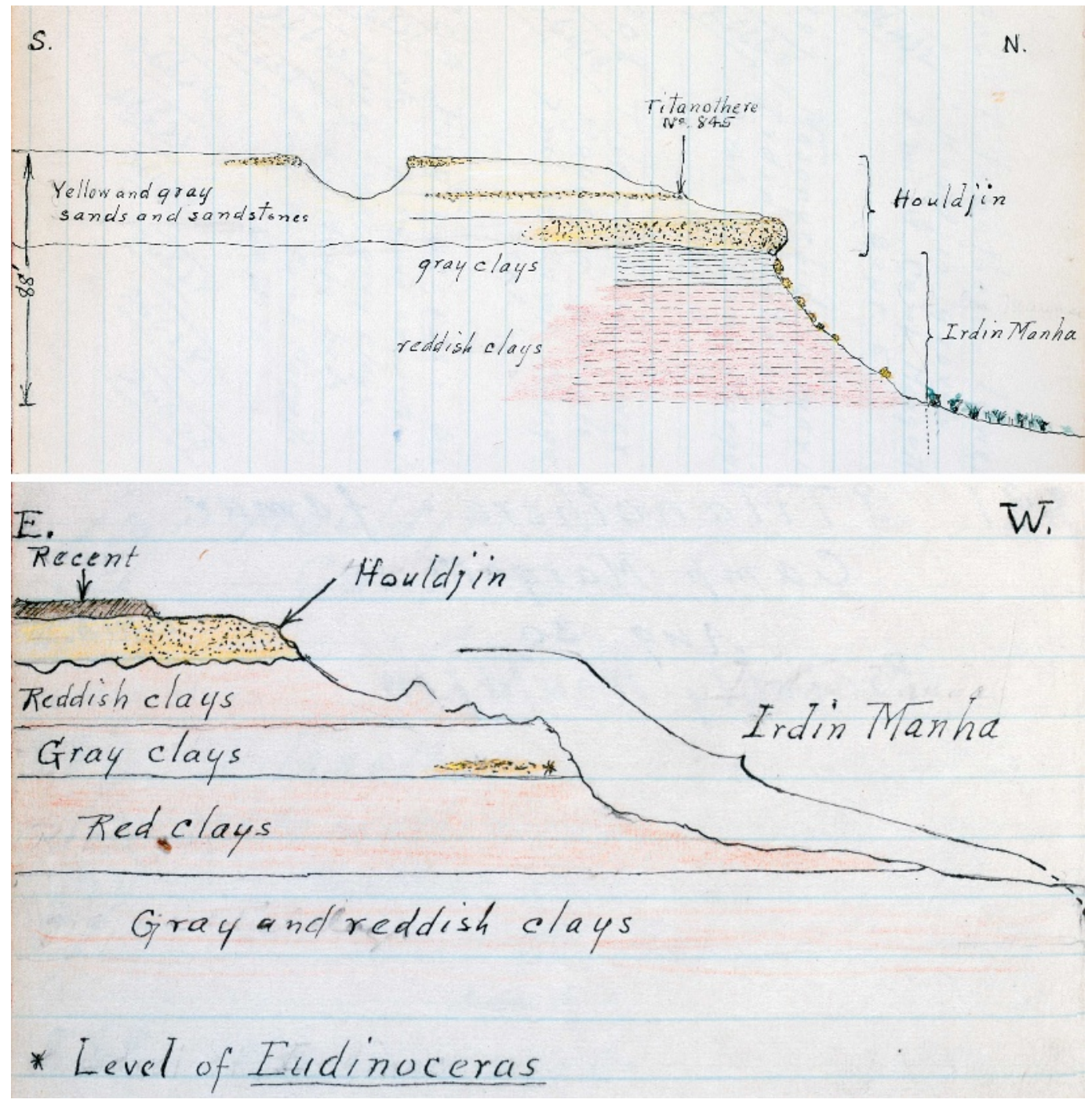

Fig. 6. Sketch profiles from (above) Camp Margetts and (below) 7 miles southwest $\left(235^{\circ}\right)$ of Camp Margetts (Granger, 1930).

dont molar fragment figured in Matthew and Granger, 1925) are recorded from the Irdin Manha beds, and most were found in the sandstones, whereas specimens collected in 1930 from the same sandstones are recorded from the "Houldjin beds", and those found in the underlying red and gray shales from the "Irdin Manha beds". It remains unclear, however, why Granger (1930) considered most of the red clays and standstone as "Irdin Manha beds" in his sketched sections at the time when the Irdin Manha Formation was already recognized as a set of gray fluvial sandstone, distinctive from the underlying Arshanto Formation, a set of red beds (Berkey and Morris, 1927). Radinsky (1964: 5) pointed out that none of these sections agrees exactly with any other or with the section measured in 1923, and concluded that: "The available evidence thus suggests that the relationship between the beds called 'Irdin Manha' in the Camp Margetts area and the type Irdin Manha beds is complex and not yet fully understood. The solution to this problem 


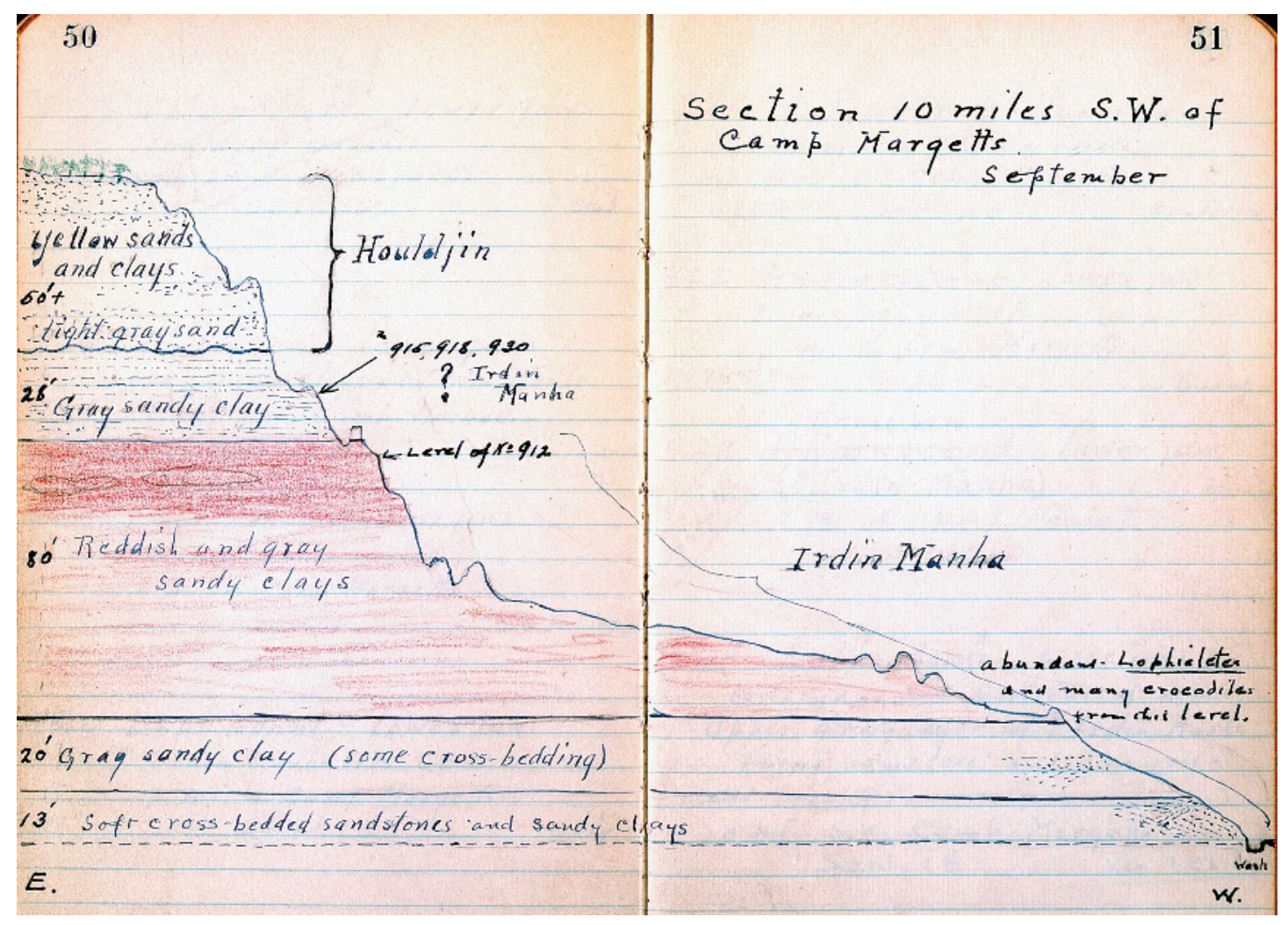

Fig. 7. Sketch profile from the locality 10 miles southwest of the Camp Margetts (Granger, 1930).

requires careful stratigraphic investigations in the critical areas and the collection of additional faunal samples with accurate stratigraphic data. At least until such is done, the terms 'Irdin Manha' and 'Houldjin' should be placed in quotation marks when strata in the Camp Margetts area are referred to, to indicate that correlation is still uncertain."

Given our relocation of localities provided above, we think Granger's (1930) sections at Camp Margetts, 7 miles southwest $\left(235^{\circ}\right)$ of Camp Margetts, and 10 miles southwest of Camp Margetts correspond roughly to the Daoteyin Obo, Wulanboerhe (Meng et al., 2004) and Huheboerhe sections, respectively (fig. 1).

The Camp Margetts section of Granger is 88 feet $(\sim 27 \mathrm{~m})$ thick and consists of the upper yellow and gray sandstones and the lower gray and red clays, similar to those in the Daoteyin Obo and Duhemingboerhe sections. Fossils from Camp Margetts and its vicinity collected by the CAE were dominated by bronthotheres, most of which are from beds considered as "Houldjin gravels" (appendix 3). Our correlation of the Daoteyin Obo and Huheboerhe sections indicate that those "Houldjin gravels" are mostly Irdin Manha beds. In a recent review of bronthotheres, Mihlbachler (in press) noted that species from the "Houldjin gravels" at Camp Margetts area are similar to those from Irdin Manha beds elsewhere and to Uintan taxa from North America. Therefore, even though the specimens were labeled as being from the "Houldjin gravels", he considered them to pertain to the Middle Eocene Irdinmanhan LMA. These observations lend support to the notion that at least most of the "Houldjin gravels" at Camp Margetts is actually Irdin Manha Formation.

However, specimens of Indricotherium transouralicum (Granger and Gregory, 1936, Wood, 1938), which is supposed to be an 
Oligocene taxon, were found in the "Houldjin gravels" from the Overnight Camp site, and postcranial elements probably belonging to the same taxon were also found on the surface of the upper exposures of the escarpment during our recent fieldwork. The presence of these fossils can be interpreted either as evidence of true Houldjin gravels in this sequence or the occurrence of Indricotherium in Irdin Manha beds. If the former is the case, the Houldjin gravels may be represented only by a thin layer of loose sand and conglomerates forming the Gobi surface.

The section at the locality 7 miles southwest $\left(235^{\circ}\right)$ of Camp Margetts drawn by Granger did not include data specifying the thickness of the beds (fig. 6). The profile is similar to the upper part of the section at Wulanboerhe (Meng et al., 2004; Bowen et al., 2005) in topography and lithology. The upper beds, called "Houldjin" by Granger, are most likely equivalent to bed 12 of Meng et al. (2004), which they considered typical of the Irdin Manha Formation. These strata are now known to form the lower part of the middle beds according to our terminology. Granger's profile did not seem to include the lower part of the lower beds (beds 1-4 of Meng et al., 2004) that slope gently to the base of the exposed section at Wulanboerhe. The "Eudinoceras" in Granger's sketch were described as Gobiatherium mirificum (Osborn and Granger, 1932). This species is the dominant taxon in terms of abundance at this site (appendix 3), and it is regarded as one of the index taxa for the Arshantan (Lucas, 2001). Although Protitan minor, a brontothere, was reported from the site 7 miles southwest of CM, Mihlbachler (in press) considered it a new species (taxon A) different from that from the site 0.5 mile west of CM. We think that the bed that contains Gobiatherium mirificum ("Eudinoceras") in Granger's section is roughly correlative with the beds that yielded Litolophus, Gobiatherium, and Metacoryphodon within the middle beds of the NHA sequence. The red clays underlying the "Eudinoceras" bed in Granger's section therefore correlate with the red bed that yielded Gomphos and Pataecops in the sections measured at Wulanboerhe and Nuhetingboerhe.
The thickness and lithology of the sketched section at 10 miles southwest of CM are close to those of our Huheboerhe section (fig. 7). Granger's section, again, may not include the lowest beds that yield specimens of Gomphos, which are exposed in a small area at the very base of the escarpment adjacent to the covered low land. The "13 feet soft-cross bedded sandstones and sandy clays" and "20 feet gray sandy clay (some cross bedding)" are probably equivalent to beds 3 and 4 in our Huheboerhe section. The beds that yield "abundant Lophialetes and many crocodiles" are most likely correlative to beds 5 and 6 in our section. Like Granger, we have collected a large number of perissodactyls and other mammals from these beds. Granger may have considered these beds as "Irdin Manha", even though they are lithologically distinctive from the type Irdin Manha Formation, because he thought the perrisodactyls from these beds were Lophialetes, a common taxon from the type Irdin Manha section. It is interesting to note, however, that although Granger's diagrammatic section cites "abundant Lophialetes and many crocodiles" from the bed above the 20 feet of gray sandy clays (fig. 7), his field notes record all Lophialetes and lophiodont specimens as being from the upper gray clay designated as "?Irdin Manha beds" on Granger's sketch drawing (appendix 3); none were actually collected from the lower beds. Granger's field notes regarding Lophialetes agree with our field observations. Our preliminary study of perissodactyl fossils collected from beds 5 and 6 shows that the dominant perissodactyl taxon is referable to Schlosseria, not Lophialetes, and that specimens of Lophialetes were collected from bed 8 or higher, as stated above.

The 28 feet of gray sandy clay on Granger's sketch bearing the field numbers 916, 918 and 930 (fig. 7; appendix 3) is probably equivalent to bed 8 of our Huheboerhe section. The top 60 some feet of yellow sands and clays on Granger's sketch likely correlate with our upper beds, or Irdin Manha Formation. As we observed in the field, the Irdin Manha beds are fluvial sediments and channel fills, which vary significantly in thickness along the same escarpment. This explains the discrepancy in 
the thickness of these beds in Granger's sketch and our measured sections.

Our correlation based on new stratigraphic observations indicates that the basal sandstones and clays in Granger's section at the site 10 miles southwest of the CM correlate with the package that includes the gray clays, reddish clays, and "Houldjin" in the section at the locality 7 miles southwest of the CM. Thus, the bulk of the section 10 miles southwest of $\mathrm{CM}$ is younger than the exposed strata at the site 7 miles southwest of the CM. The entire "Irdin Manha" in Granger's section at the locality 10 miles southwest of CM should be Arshanto Formation, and his "Houldjin", and probably the "?Irdin Manha" as well, should be Irdin Manha Formation. In Granger's section at the site 7 miles southwest $\left(235^{\circ}\right)$ of $\mathrm{CM}$, beds below the gray clays containing "Eudinoceras" belong to the Nomogen formation (see below), and the rest are Arshanto Formation, not Irdin Manha or Houldjin gravels. These correlations indicate that previous ideas about the stratigraphy of this region were fundamentally flawed and that classical conceptions of the Arshanto and Irdin Manha faunas were based on heterogeneous fossil assemblages from different stratigraphic levels.

OTHER SECTIONS: Qi's (1987) section at Huhe Bulak, which we think is part of the Huheboerhe escarpment, is generally comparable to the section we measured at Huheboerhe in its recognition of rock units. It differs from our section in being thinner, with a total thickness of $41.99 \mathrm{~m}$ and in failing to recognize the upper hiatus. Fossils including Gobiatherium and Schlosseria magister occur at a relatively higher level compared to our records. Moreover, Qi's section includes the lower part of the Nomogen Formation because of the presence of Prodinoceras; this contradicts our observation that the Gomphos bed is by far the lowest bed we observed at the Huheboerhe section. However, given that we are not certain about the exact location of Qi's section and that the lithology and thickness vary laterally along the escarpment, these variances are not surprising.

Qi's (1987) Arshanto fauna, the basis of the Arshantan LMA (Tong et al., 1995; Lucas, 2001), consists of fossils collected from a dozen widely scattered localities, including the Irdin Manha area, Huhe Bulak, Daatein Obo, Bayan Ulan, Ulan Bulak, 8 miles north of Tukhum Lamasery; the Ulan Shireh area, 25 miles southwest of Iren Dabasu, Arshanto Obo, near Camp Margetts, Camp Margetts, and North Mesa. Given our stratigraphic correlation of the NHA, some of the fossils included by Qi (1987) in his composite Arshanto fauna are almost certainly from the Irdin Manha Formation.

Jiang's Wulanboerhe section (1983) reflects a drastically different stratigraphic conception of the region (Some of the terminologies used therein are tabulated in appendix 1). The measured part of the section totals $44.94 \mathrm{~m}$ in thickness and comprises four formations. The "Bayan Ulan Formation" is another lithological unit of the sequence, but its thickness was not specified. The section and the listed fossils appear to be composite.

\section{DEFINITION OF FORMATIONS REVISITED}

Irdin Manha Formation: As mentioned above, the Irdin Manha Formation was found about $33 \mathrm{~km}$ southeast of the modern city of Erlian (Granger and Berkey, 1922; Berkey and Morris, 1924, 1927; see also Russell and Zhai, 1987). At the type locality for the Irdin Manha Formation, the strata are predominantly gray beds of sandy clay, sand, and gravel that are characterized by numerous channel-cuts and fills (Berkey and Morris, 1927). Two peculiarities of the Irdin Manha beds were mentioned by Berkey and Morris. One is the presence of innumerable white marly or limy lumps, like concretions. The other is the lustrous polish of the pebbles contained in the unit. Berkey and Morris (1927: 208) noted: "The handsome lustrous stones have given the place its name, for Irdin Manha means 'Valley of Gems"'.

Different thicknesses of Irdin Manha formation have been documented in previous studies. In the first report on the formation (Granger and Berkey, 1922), the Irdin Manha Formation was considered to be 24 to 29 feet thick. In a subsequent study (Berkey and Morris, 1924), the sequence was cited as being 40 to 100 feet thick. Because the sequence was later divided into two formations (the re- 
stricted Irdin Manha Formation above and the new Arshanto Formation below), the thickness of each should be less than the figures reported. In later studies, the thickness of the Irdin Manha at its type locality was considered to be $10 \mathrm{~m}$ (Russell and Zhai, 1987). Qi (1987: 10) noted that "the thickness of the type Irdin Manha beds is $41 \mathrm{~m}$ ", although the thickness of Irdin Manha beds in the section at Arshanto Obo was given as $10.13 \mathrm{~m}$ (Qi, 1987: 5). Based on our observation at several outcrops of Irdin Manha escarpments, we concur that the restricted Irdin Manha Formation is $10-15 \mathrm{~m}$ in thickness at its type area. Irdin Manha beds were reported to be about $5 \mathrm{~m}$ at the Huheboerhe cliff (Qi, 1980), $5.4 \mathrm{~m}$ at Huhe Bulak (Qi, 1987), and $41.1 \mathrm{~m}$ at Bayan Ulan (Qi, 1987). However, the $41.1 \mathrm{~m}$ "Irdin Manha" beds at Bayan Ulan include a $27.5 \mathrm{~m}$ thick package of red beds, which was subsequently correlated with the Shara Murun Formation (Meng et al., 1999).

The Irdin Manha Formation can be defined as a set of gray beds dominated by fluvial sandy clay, sand, and gravel and characterized by numerous channel-cuts and fills. Its lower limit is marked by an erosional surface equivalent to an interval of time at the type locality, which can be correlated to the upper hiatus in the NHA. This erosional surface is uneven and the thickness of the Irdin Manha Formation varies from place to place. At the Huheboerhe transect, it is $9.8 \mathrm{~m}$ thick. Its upper limit is unknown at the type locality, but may be overlain by the Shara Murun Formation in the Bayan Ulan area. The age of the Irdin Manha Formation is conventionally regarded as Middle Eocene.

Arshanto Formation: Berkey and Morris (1927) named the lower red beds of the original Irdin Manha Formation as the Arshanto Formation (see also Matthew and Granger, 1926). Therefore, the Arshanto and Irdin Manha formations share the same type locality. The name Arshanto came from part of a broad, undrained hollow about 1 mile east of the Irdin Manha escarpment (Berkey and Morris, 1927). Although the precise locality of "Irdin Manha" is uncertain today, examples that show the same lithology and superpositional relationship of beds can be found along excarpments south and southeast of Iren Dabasu.

The base of the Arshanto Formation was not observed at any outcrop in the Irdin Manha area. Berkey and Morris (1927) thought the formation rests upon Cretaceous beds, based on their belief that the Arshanto Formation correlates with the so-called barren beds at Iren Dabasu. However, the lithology of the barren beds at Iren Dabasu is different from the Arshanto beds at Irdin Manha. At Irdin Manha, the red beds are "prevailingly red clays and fine silts, which, on weathering, crumble into small hard chips. Much of the deposit is structureless, almost like loess; however, it lacks the vertical cleavage and the concretions so commonly noted in loess" (Berkey and Morris, 1927: 207). The barren clays above the Cretaceous beds at Iren Dabasu are "distinctly shaly and well bedded; there is no doubt that they, at least, were laid down in water" (ibid.).

Qi (1987) divided the CAE's "Arshanto Formation" into three units, the late Paleocene Nomogen beds, the early Eocene Bayan Ulan beds, and the middle Eocene Arshanto beds. Qi grouped the Nomogen and Bayan Ulan beds into the Nomogen Formation, whereas the Arshanto beds and overlying Irdin Manha beds were associated in the Irdin Manha Formation. Although Qi (1987) suggested that the Nomogen Formation (his definition) could be distinguished from the Arshanto beds by the presence of celestite nodules therein, these purported differences are not distinctive (Meng, 1990). Because the Arshanto and Irdin Manha rocks are lithologically distinctive, Meng (1990) suggested that they be retained as separate formations.

The lower hiatus present in several sections at the NHA is a good stratigraphic marker, which we recognize as the lower limit of the Arshanto Formation. The Arshanto Formation thus defined is best exposed in the Huheboerhe section, where its lower and upper limits are both present and the formation measures $35.2 \mathrm{~m}$ in thickness. The Arshanto Formation in our usage is expanded to encompass more strata than it did conventionally. In particular, it consists not only of a set of reddish clays, but also of gray, fluvial 
coarse sediments with cross-bedding structures in its basal beds. The lithology gradually grades into finer sandstone and clays upward. Reddish clays exist mostly in the upper part of the formation. This sequence probably represents a large-scale sedimentological cycle. The age of the Arshanto Formation was traditionally considered to be Middle Eocene, but with the expansion of its lithological content, the formation probably spans from the late Early Eocene to early Middle Eocene. The basal part of the Arshanto Formation is characterized by presence of several large mammals, including Metacoryphodon, Gobiatherium, and Litolophus, as well as numorious primitive rodents and lagomorphs.

Nomogen Formation: The Nomogen Formation was used informally by the Geological Survey of Nei Mongol and was first reported by Zhou et al. (1976). At its type locality, Haliut, the formation consists of three levels of approximately $16 \mathrm{~m}$ aggregate thickness (reported as $14 \mathrm{~m}$ in Russell and Zhai, 1987; see also Meng et al., 1998) and produced a mammalian fauna traditionally considered to be late Paleocene (Zhou et al., 1976; Zhou and Qi, 1978). The formation is mainly composed of red sandy clays of lacustrine orign (Russell and Zhai, 1987). The bottom of the formation is not exposed. Similar beds have been reported from the Huheboerhe, Bayan Ulan, Urdyn Obo, and Subeng localities (Jiang, 1983; Qi, 1987; Meng, 1990; Meng et al., 1998), but they all vary in lithology to some degree. In addition to the Nomogen Formation, "Bayan Ulan Formation" has been proposed (Jiang, 1983), but this concept was subsequently abandoned (Qi, 1987; BGMRNMAR, 1991; Meng et al., 1998) because it was based primarily on its fossil content, not its lithology. Meng et al. (1998) suggested that the basal beds at Bayan Ulan are laterally equivalent to the Nomogen Formation. Both the Nomogen and the Arshanto formations contain reddish clays and are only partly exposed at their type localites; their precise stratigraphic relationship has never been made clear, although fossils indicated that the Nomogen Formation is older than the Arshanto Formation.

The lower hiatus in the NHA sections provides a clear-cut upper boundary for the
Nomogen Formation, but its lower limit remains unknown. The Nomogen Formation recognized here measures $37.5 \mathrm{~m}$ thick at Nuhetingboerhe, which is significantly thicker than the sequence recognized at its type locality. The lithology is characterized by variegated sandstone, sandy clays and clays, with more reddish beds in the upper part of the formation. The formation contains at least two distinctive faunas, the Gashatan Lambdopsalis fauna below and the Bumbanian Gomophos fauna above, and is currently estimated as ranging from the Late Paleocene to Earliest Eocene.

\section{CONCLUSION}

New stratigraphic data show that the sequence at the NHA, or Camp Margetts area, Nei Mongol, comprises three lithological units, the Nomogen, Arshanto, and Irdin Manha formations, with a thickness of $82.4 \mathrm{~m}$. It contains faunas from four Asian LMA (Gashatan, Bumbanian, Arshantan, and Irdinmanhan) that span the time interval from Late Paleocene to Middle Eocene. For the first time, the superpositional relationships of these formations and faunas can be demonstrated in one sequence. These data also show that previous understanding of the stratigraphy in the NHA was largely incorrect. The so-called "Houldjin gravels" of the CAE are mostly Irdin Manha Formation or Arshanto Formation and the "Irdin Manha beds" of the CAE mostly belong to either the Arshanto Formation or the Nomogen Formation. These correlations reveal that classical notions of the composition of the Irdin Manha and Arshanto faunas, which include fossils from the beds of the NHA, are based on heterogeneous samples from different stratigraphic horizons. Because these mixed faunal assemblages have served as the foundation for the Asian Eocene Arshantan and Irdinmanhan land mammal ages, previous discussions on regional and intercontinental biostratigraphic correlation, regional biochronology, and faunal evolution during this period of time are problematic. To clarify these problems requires a systematic study of regional stratigraphy, a review of all fossils collected from 
the region, and the establishment of a regional time scale that is independent of fossils, such as a magnetostratigraphic sequence.

\section{ACKNOWLEDGEMENTS}

We thank Gabriel J. Bowen, Qiang Cao, Wei Gao, Daniel L. Gebo, Paul L. Koch, Chun Li, Ping Li, Qiang Li, Shijie Li, Suyin Ting, Rui Yang, Jie Ye and Wei Zhou for field assistance; Chuankui Li, Zhanxiang Qiu, and Banyue Wang for discussion; Drs. Malcolm C. McKenna and Spencer Lucas for comments on the manuscript. This project has been supported by the National Natural Science Foundation of China (40532010), U.S. National Science Foundation grants (EAR0120727, BCS-0309800), and the Major Basic Research Projects of MST of China (2006CB806400).

\section{REFERENCES}

Asher, R.J., J. Meng, M.C. McKenna, J.R. Wible, D. Dashzeveg, G. Rougier, and M.J. Novacek. 2005. Stem Lagomorpha and the Antiquity of Glires. Science 307: 1091-1094.

Averianov, A.O. 1994. Early Eocene mimotonids of Kyrgyzstan and the problem of Mixodontia. Acta Palaeontologica Polonica 39: 393-411.

Averianov, A.O., and M. Godinot. 1998. A report on the Eocene Andarak mammal fauna of Kyrgyzstan. In K.C. Beard and M.R. Dawson (editors), Dawn of the age of mammals in Asia, Bulletin of the Carnegie Museum of National History 34: 124-147.

Averianov, A.O., and M. Godinot. 2005. Ceratomorphs (Mammalia, Perissodactyla) from the early Eocene Andarak 2 locality in Kyrgystan. Geodiversitas 27: 221-234.

Averianov, A.O., and A.V. Lopatin. 2005. Eocene Lagomorphs (Mammalia) of Asia: 1. Aktashmys (Strenulagidae fam. nov.). Paleontological Journal 39: 308-317, [Translated from Paleontoliicheskii Zhurnal 3: 81-90]

Bai, B. 2006. New materials of Eocene Dinocerata (Mammalia) from the Erlian Basin, Nei Mongol (Inner Mongolia). Vertebrata PalAsiatica 44: 250-261.

Beard, K.C., and M.R. Dawson. 1999. Intercontinental dispersal of Holarctic land mammals near the Paleocene-Eocene boundary: paleogeographic, paleoclimatic and bio- stratigraphic implications. Bulletin de la Société Géologique de France 170: 697-706.

Berkey, C.P., and W. Granger. 1923. Later sediments of the desert basins of central Mongolia. American Museum Novitates 77: $1-16$.

Berkey, C.P., and F.K. Morris. 1924. Basin structures in Mongolia. Bulletin of the American Museum of Natural History 50: 103-127.

Berkey, C.P., and F.K. Morris. 1927. Geology of Mongolia - a reconnaissance report based on the investigations of the years 1922-1923. Natural History of Central Asia, Volume, $475 \mathrm{pp}$.

BGMRNMAR (Bureau of Geology and Mineral Resources of Nei-Mongol Autonomous Region). 1991. Regional geology of NeiMongol (Inner Mongolia) autonomous region. Geological Memoirs (1)25: 1-725.

Bowen, G.J., P.L. Koch, J. Meng, J. Ye, and S.-Y. Ting. 2005. Age and correlation of fossiliferous Late Paleocene-Early Eocene strata of the Erlian Basin, Inner Mongolia, China. American Museum Novitates 3474: 1-26.

Chow, M.-C., and A.K. Rozhdestvensky. 1960. Exploration in Inner Mongolia - a preliminary account of the 1959 field work of the SinoSoviet Paleontological Expedition (SSPE). Vertebrate PalAsiatica 4: 1-10.

Colbert, E.H. 1934. Chalicotheres from Mongolia and China in the American Museum. Bulletin of the American Museum of Natural History 67: 353-387.

Dashzeveg, D. 1988. Holarctic correlation of nonmarine Palaeocene-Eocene boundary strata using mammals. Journal of the Geological Society (London) 145: 473-478.

Dashzeveg, D. 1990. The earliest rodents (Rodentia, Ctenodactyloidea) of Central Asia. Acta Zoologica Cracoviensia 33: 11-35.

Dashzeveg, D. 1991. Hyracodontids and rhinocerotids (Mammalia, Perissodactyla, Rhinocerotoidea) from the Paleogene of Mongolia. Palaeovertebrata 21: 1-84.

Dashzeveg, D., and J.J. Hooker. 1997. New ceratomorph perissodactyls (Mammalia) from the Middle and Late Eocene of Mongolia: their implications for phylogeny and dating. Zoological Journal of the Linnean Society 120: 105-138.

Dawson, M.R. 1964. Late Eocene rodents (Mammalia) from Inner Mongolia. American Museum Novitates 2191: 1-15.

Emry, R.J., and W.W. Korth. 1989. Rodents of the Bridgerian (Middle Eocene) Elderberry Canyon Local Fauna of eastern Nevada. Smithsonian Contributions to Paleobiology 67: 1-14. 
Emry, R.J., L.A. Tyutkova, S.G. Lucas, and B.-Y. Wang. 1998. Rodents of the Middle Eocene Shinzhaly Fauna of Eastern Kazakhstan. Journal of Vertebrate Paleontology 18: 218-227.

Gingerich, P.D. 1993. Early Eocene Teilhardina brandti: oldest omomyid primate from North America. Contributions from the Museum of Paleontology, University of Michigan 28: 321-326.

Granger, W. 1930. Records of fossils collected in Mongolia. Central Asiatic Expeditions, New York: American Museum of Natural History.

Granger, W., and C.P. Berkey. 1922. Discovery of Cretaceous and older Tertiary strata in Mongolia. American Museum Novitates 42: $1-7$.

Granger, W., and W.K. Gregory. 1936. Further notes on the gigantic extinct rhinoceros, Baluchitherium, from the Oligocene of Mongolia. Bulletin of the American Museum of Natural History 72: 1-73.

Granger, W., and W.K. Gregory. 1938. A new titanothere genus from the upper Eocene of Mongolia and North America. Bulletin of the American Museum of Natural History 74: $435-436$.

Granger, W., and W.K. Gregory. 1943. A revision of the Mongolian titanotheres. Bulletin of the American Museum of Natural History 80: 349-389.

Jiang, H.-X. 1983. Division of the Paleogene in the Erlian Basin of Inner Mongolia. Geology of Inner Mogolia 2: 18-36. [in Chinese]

Li, C.-K., J. Meng, and Y.-Q. Wang. In press. Dawsonolagus antiquus, a primitive lagomorph from the Eocene Arshanto Formation. Inner Mongolia, China: Bulletin of the Carnegie Museum of National History.

Li, C.-K., and S.-Y. Ting. 1983. The Paleogene mammals of China. Bulletin of Carnegie Museum of Natural History 21: 1-98.

Lucas, S.G. 1998. Fossil mammals and the Paleocene/Eocene series boundary in Europe, North America, and Asia. In M.-P. Aubry, S. Lucas and W.A. Berggren (editors), Late Paleocene-Early Eocene Events in the marine and terrestrial records: 451-500. New York: Columbia University Press.

Lucas, S.G. 2001. Gobiatherium (Mammalia: Dinocerata) from the Middle Eocene of Asia: taxonomy and biochronological significance. Paläontologische Zeitschrift 74: 591-600.

Lucas, S.G., and R.J. Emry. 2001. Sharamynodon (Mammalia: Perissodactyla) from the Eocene of the Ily basin, Kazakstan and the antiquity of Asian amynodonts. Proceedings of the
Biological Society of Washington 114: $517-$ 525.

Luterbacher, H.P., J.R. Ali, H. Brinkhuis, F.M. Gradstein, J.J. Hooker, S. Monechi, J.G. Ogg, J. Powell, U. Röhl, A. Sanfilippo, and B. Schmitz. 2004. The Paleogene Period. In F. Gradstein, J. Ogg and A. Smith (editors), A geological time scale 2004: 384408. Cambridge: Cambridge University Press.

Matthew, W.D., and W. Granger. 1925. Fauna and correlation of the Gashato Formation of Mongolia. American Museum Novitates 189: $1-12$.

Matthew, W.D., and W. Granger. 1926. Two new perissodactyls from the Arshanto Eocene of Mongolia. American Museum Novitates 208: $1-5$.

McKenna, M.C., and S.K. Bell. 1997. Classification of mammals above the species level. New York: Columbia University Press.

Meng, J. 1990. A new species of Didymoconidae and comments on related locality and stratigraphy. Vertebrata PalAsiatica 28: 206-217.

Meng, J., G.J. Bowen, J. Ye, P.L. Koch, S.-y. Ting, Q. Li, and X. Jin. 2004. Gomphos elkema (Glires, Mammalia) from the Erlian Basin: evidence for the Early Tertiary Bumbanian Land Mammal Age in Nei-Mongol, China. American Museum Novitates 3425: 1-24.

Meng, J., C.-K. Li, X.-J. Ni, Y.-Q. Wang, and K.C. Beard. In press. A new Eocene rodent from the lower Arshanto Formation in the Nuhetingboerhe (Camp Margetts) area, Inner Mongolia

Meng, J., and M.C. McKenna. 1998. Faunal turnovers of Palaeogene mammals from the Mongolian plateau. Nature 394: 364-367.

Meng, J., A.R. Wyss, Y.-M. Hu, Y.-Q. Wang, G.J. Bowen, and P.L. Koch. 2005. Glires (mammalia) from the late Paleocene Bayan Ulan Locality of Inner Mongolia. American Museum Novitates 3473: 1-25.

Meng, J., J. Ye, and X.-S. Huang. 1999. Eocene mammals from the Bayan Ulan of Nei Mongol (Inner Mongolia) and comments on related stratigraphy. Vertebrata PalAsiatica 37: 165174.

Meng, J., R.-J. Zhai, and A.R. Wyss. 1998. The late Paleocene Bayan Ulan fauna of Inner Mongolia, China. Special volume of the Symposium on Cretaceous and Early Tertiary Mammals of Asia. Bulletin of Carnegie Museum of Natural History 34: 148-185.

Mihlbachler, M.C. In press. Species taxonomy, phylogeny, and biogeography of the Brontotheriidae (Mammalia: Perissodactyla). Bulletin of the American Museum of Natural History. 
Morris, F.K. 1923. Geological field notes. Book II. Central Asiatic Expeditions. New York: American Museum of Natural History.

Ni, X.-J., C.K. Beard, J. Meng, Y.-Q. Wang, and D. Gebo. In press. Baataromomys ulaanus gen. and sp. nov., an Early Eocene euprimate from Inner Mongolia.

Osborn, H.F., and W. Granger. 1932. Coryphodonts and uintatheres from the Mongolian expedition of 1930. American Museum Novitates 552: 1-16.

Qi, T. 1979. A general account of the early Tertiary mammalian faunas of Shara Murun area, Inner Mongolia. 2nd Congress of Stratigraphy, Peking, China: 1-9.

Qi, T. 1980. Irdin Manha Upper Eocene and its mammalian fauna of Huhebolhe Cliff in Central Inner Mongolia. Vertebrata PalAsiatica 18: 28-32.

Qi, T. 1987. The Middle Eocene Arshanto fauna (Mammalia) of Inner Mongolia. Annals of Carnegie Museum 56: 1-73.

Radinsky, L.B. 1964a. Notes on Eocene and Oligocene fossil localities in Inner Mongolia. American Museum Novitates 2180: 1-11.

Radinsky, L.B. 1964b. Paleomoropus, a new Early Eocene chalicothere (Mammalia, Perissodactyla), and a revision of Eocene chalicotheres. American Museum Novitates 2179: 1-28.

Radinsky, L.B. 1965. Early Tertiary Tapiroidea of Asia. Bulletin of the American Museum Natural History 129: 183-263.
Radinsky, L.B. 1966. Pataecops, new name for Pataecus Radinsky, 1965. Journal of Paleontology 40: 222.

Russell, D.E., and R.-J. Zhai. 1987. The Palaeogene of Asia: mammals and stratigraphy. Sciences de la Terre Series C 52: 1-488.

Shevyreva, N.S. 1984. New Early Eocene Rodents from the Zaysan Basin. In L.K. Gabunia (editor), Flora i fauna Zaysanskoi vpadiny, Akademiya Nauk Gruzinskoy SSR, pp. 77-114. [in Russian]

Tong, Y.-S. 1997. Middle Eocene small mammals from Liguanqiao Basin of Henan Province and Yuanqu Basin of Shanxi Province. Central China. Paleontologica Sinica, 18, New Series C, 26: 189-256. [in Chinese with English summary]

Tong, Y.-S., S.-H. Zheng, and Z.-D. Qiu. 1995. Cenozoic mammal ages of China. Vertebrata PalAsiatica 33: 290-314.

Wood, H.E. 1938. Cooperia totadentata, a remarkable rhinoceros from the Eocene of Mongolia. American Museum Navitates 1012: 1-20.

Zhou, M.-Z., and T. Qi. 1978. Paleocene mammalian fossils from Nomogen Formation of Inner Mongolia. Vertebrata PalAsiatica 16: 77-85. [In Chinese]

Zhou, M.-Z., T. Qi, and Y. Li. 1976. Paleocene stratigraphy and faunal characters of mammalian fossils of Nomogen commune, Si-zi-wang Qi, Nei Mongol. Vertebrata PalAsiatica 14: 228-233. 


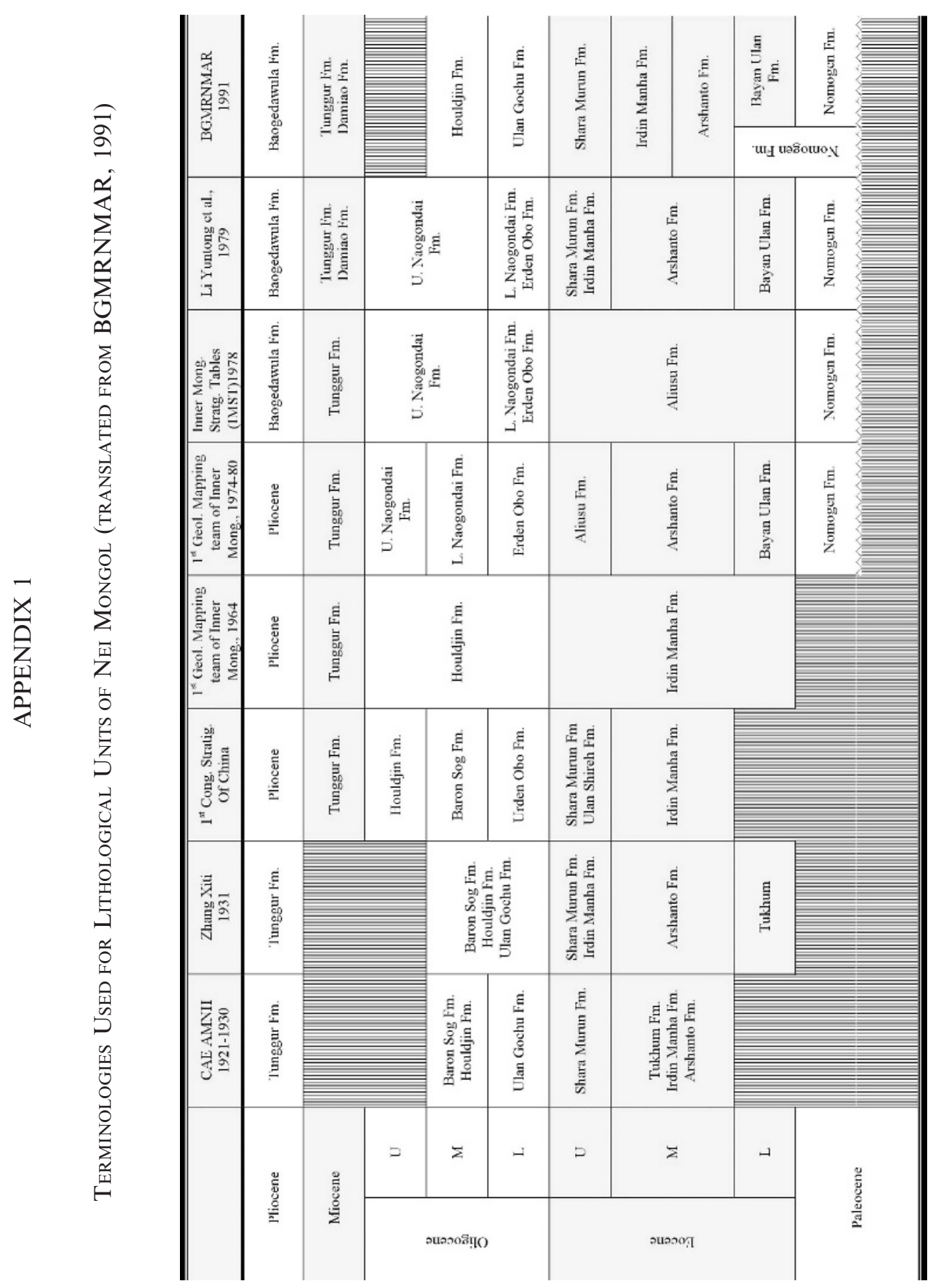




\section{APPENDIX 2}

Sections Measured from the

Nuhetingboerhe-Huheboerhe Area by Jiang (1983) AND QI (1987)

A. Huhe Bulak Section (Qi, 1987)

\section{Irdin Manha Formation}

Middle Eocene Irdin Manha beds

11. Gray-white on surface, but gray-yellow inside, sandstone and sandy gravels with many cylinder-like calcareous masses; having gray sandy conglomerate and sandstone; gravels often black quartz, the diameter $1 \mathrm{~cm}$ or so, with Andrewsarchus (=Paratriisodon; McKenna, personal commun. [McKenna and Bell, 1997: 366]) gigas, etc. (77037) . 5.4 m

\section{—unconformity (= base of channel) -}

Middle Eocene Arshanto beds

10. Top: dark gray-green-pink sandy clay. UPPER PART: yellow-green fine sandstone. ВоTTOM: gray-green sandy "conglomerates" ("gravels" mainly being muddy masses and quartz, etc., diameter $0.2 \mathrm{~cm}$ ), with Gobiaherium, Mesonyx obtusidens, Schlosseria magister, etc. $(77036-2) \ldots \ldots \ldots \ldots .6 .0$ m

9. UPPER PART: dark red clay with fossil mammal fragments and calcareous-nodules, diameter $1.5 \mathrm{~cm}$. LOWER PART: brown clay with few manganese nodules.......... $4.04 \mathrm{~m}$

8. Red-gray muddy siltstone (white on surface), with few mammalian incisors and fragments (77036-H8) . . . . . . . . . $4.85 \mathrm{~m}$

7. Brown-loess-red clay, with manganese nodules, the diameter $0.5 \mathrm{~cm}$; bearing few limb bones of Dinocerata (77036-H7). . . . . . $5.1 \mathrm{~m}$

6. Light loess-red siltstone . . . . . . . $0.3 \mathrm{~m}$

5. Brown muddy siltstone (white on surface) with few calcareous nodules, bearing Sinosinopa sinensis $(77036-\mathrm{H} 5) \ldots \ldots \ldots \ldots 2.0 \mathrm{~m}$

4. Brown-gray sandy conglomerates (gray on surface), gravels mainly a lot of muddy masses and colorless, black, or yellow-green quartz grains, with many fossil tapirs, fragments of turtles and crocodiles. Fining upward.............. $3.04 \mathrm{~m}$

3. Dark red or gray-green variegated clay, with few quartz grains and calcareous nodules, bearing astragali of Dinocerata (77036-H3). Gray-green clay decreased and manganese nodules apparent up section . . . . $6.5 \mathrm{~m}$

\section{—disconformity-}

\section{Nomogen Formation}

Lower Eocene Bayan Ulan beds

2. Brick-red sandy clay with few nodules and many bone fragments, bearing fossil tapirs, Dinocerata (Prodinoceras sp. = Mongolotherium; McKenna, personal commun. [McKenna and Bell, 1997, 358]) (77035) . . . . . . . . . . . $2.76 \mathrm{~m}$

1. Loess-red and gray-green clay with many calcareous nodules between $5-10 \mathrm{~cm}$ diame-

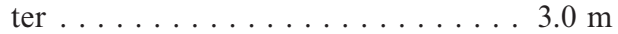

\section{_ base not visible-}

B. Wulanboerhe Section (Jiang, 1983; original in Chinese) Quaternary sands on mesa surface.Upper Naogangdai Formation $\left(E_{3} s\right)$

10. Light-yellowish pebbly sandstone. . . $1.07 \mathrm{~m}$

\section{- disconformity-}

\section{Aliusu Formation $\left(\mathbf{E}_{2} \mathbf{a l}\right)$}

9. Light-brownish red clays interbedded with grayish-green clays and gray or pink sandstone. Teleolophus sp.. . . . . . . . $10.48 \mathrm{~m}$

8. Grayish-white fine sandstone with lens of pebbly coarse sandstone. Fossils include Gobiatherium sp., Lophialetes sp., Gobiatherium? major, Metacoryphodon luminis, Teleolophus rechus, Eurgletes [Teleolophus] magnus, Schlosseria sp., Eudinoceras sp., and Breviodon sp. .......... $6.6 \mathrm{~m}$

\section{- disconformity —}

\section{Arshanto Formation $\left(\mathrm{E}_{2} \mathrm{a}\right)$}

7. Reddish clays, with the upper portion darker in color, containing gypsum and fossils, in- 
cluding Teleolophus primaries, Teleolophus sp. and Schlosseria sp. ........ $7.32 \mathrm{~m}$

\section{Bayan Ulan Formation $\left(\mathbf{E}_{2} \mathbf{b}\right)$}

6. Grayish-green clay above and light-brownish clays below, and locally with calcareousnodules. Mongolotherium sp. was collected from a site $3 \mathrm{~km}$ south of the section .... $\ldots \ldots \ldots \ldots \ldots \ldots$ [no thickness]

\section{Nomogen Formation}

5. Light-reddish, grayish green muddy siltstone with calcareous-nodules. Fossils include Hyopsodontidae and Palaeostylops iturus . . $4.9 \mathrm{~m}$
4. Grayish, yellowish-green sandy clays with interbedded lens of reddish clay. Palaeostylops iturus and Lambdopsalis bulla................. $3.3 \mathrm{~m}$

3. Grayish-green, earthy muddy siltstone, with small calcareous-nodules and lens of sandstone. Palaeostylops iturus, Prionesus lucifer, Lambdopsalis bulla and Prodinoceras sp. . . . . . . . . . . . . . $4.27 \mathrm{~m}$

2. Variegated clays with grayish white siltstone, with gypsum and fossils: Prodinoceras sp. and Palaeostylops iturus . . . . . . . $6.35 \mathrm{~m}$

1. Grayish-green clays. . . . . . . . > $>0.65 \mathrm{~m}$ 


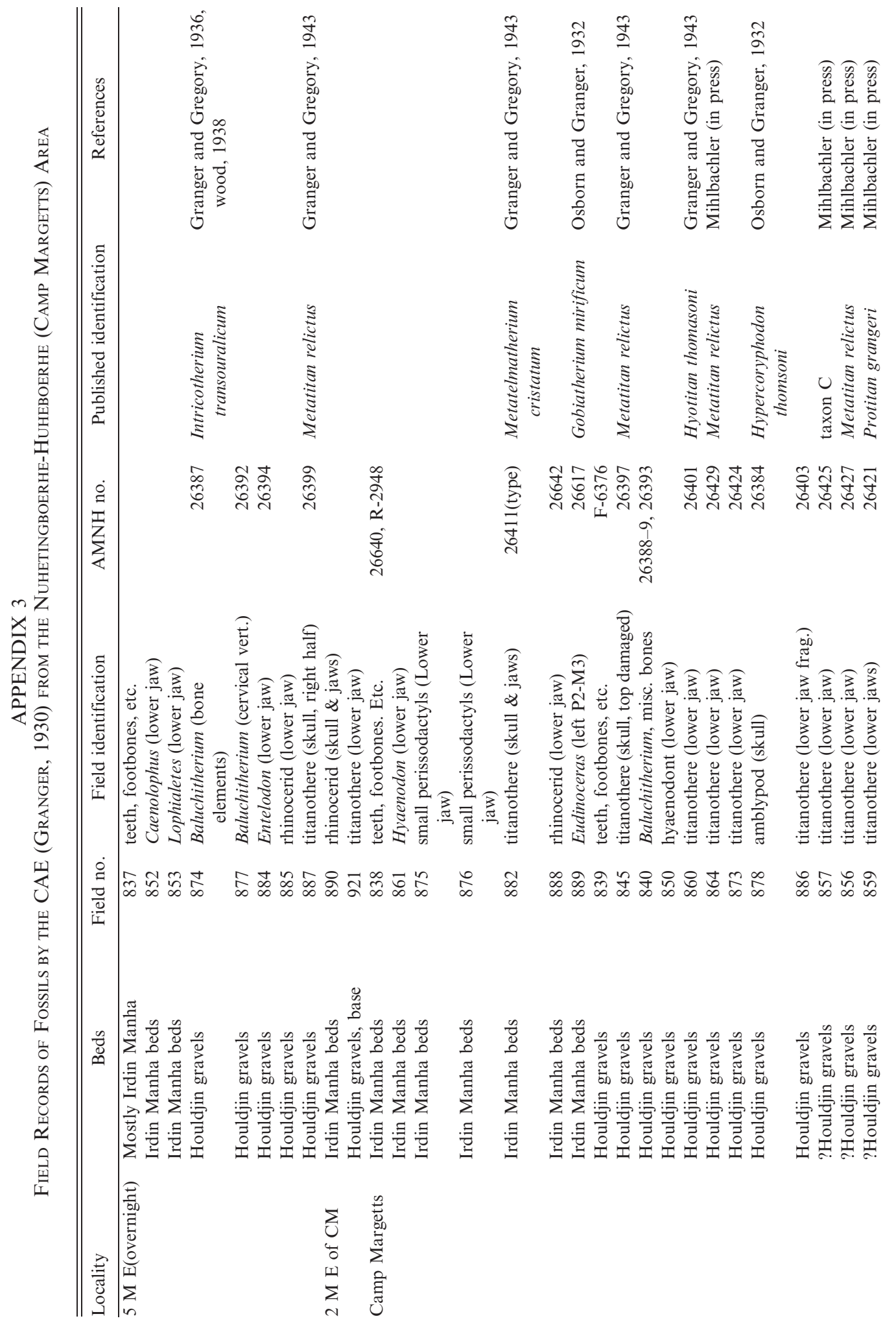




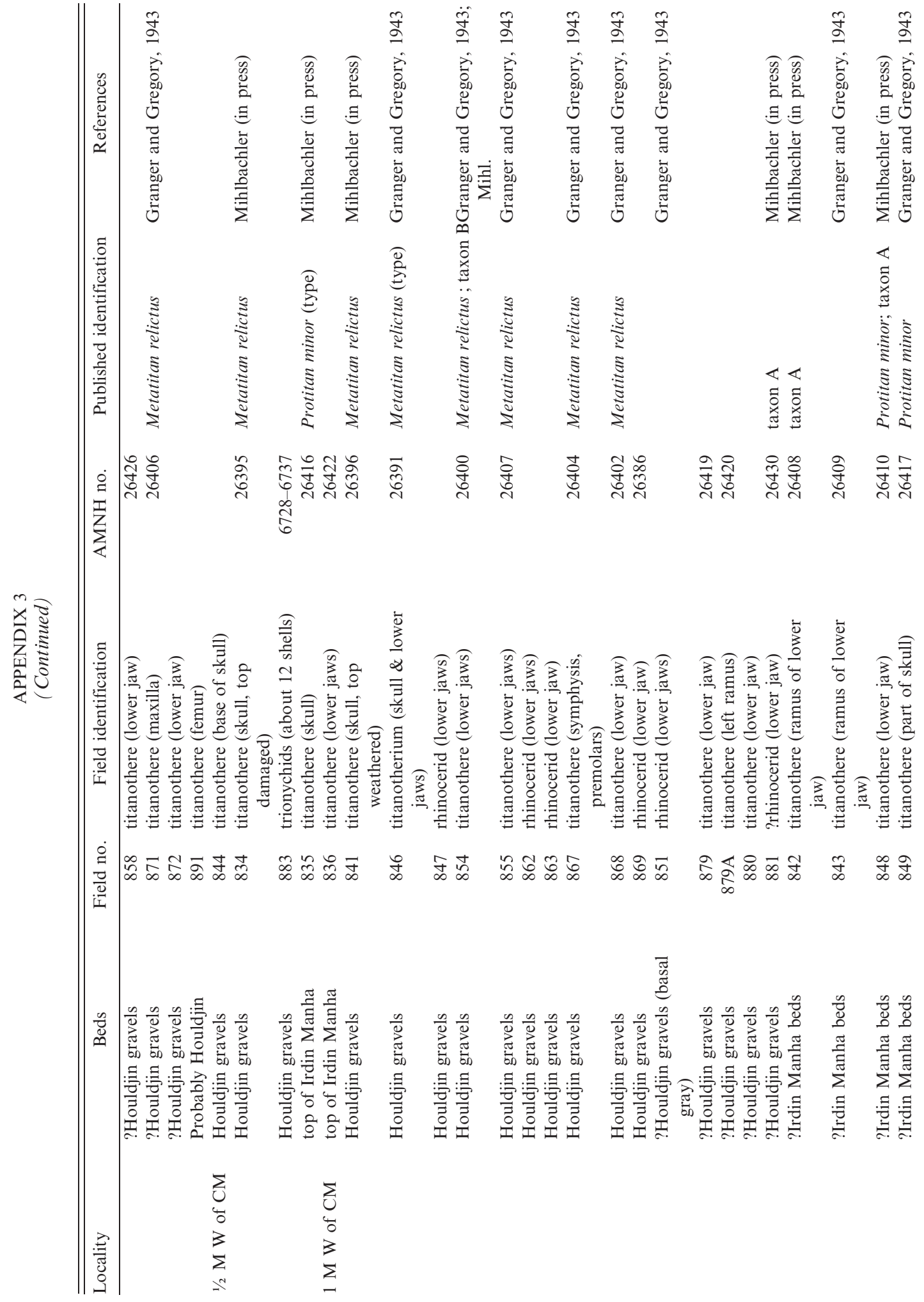




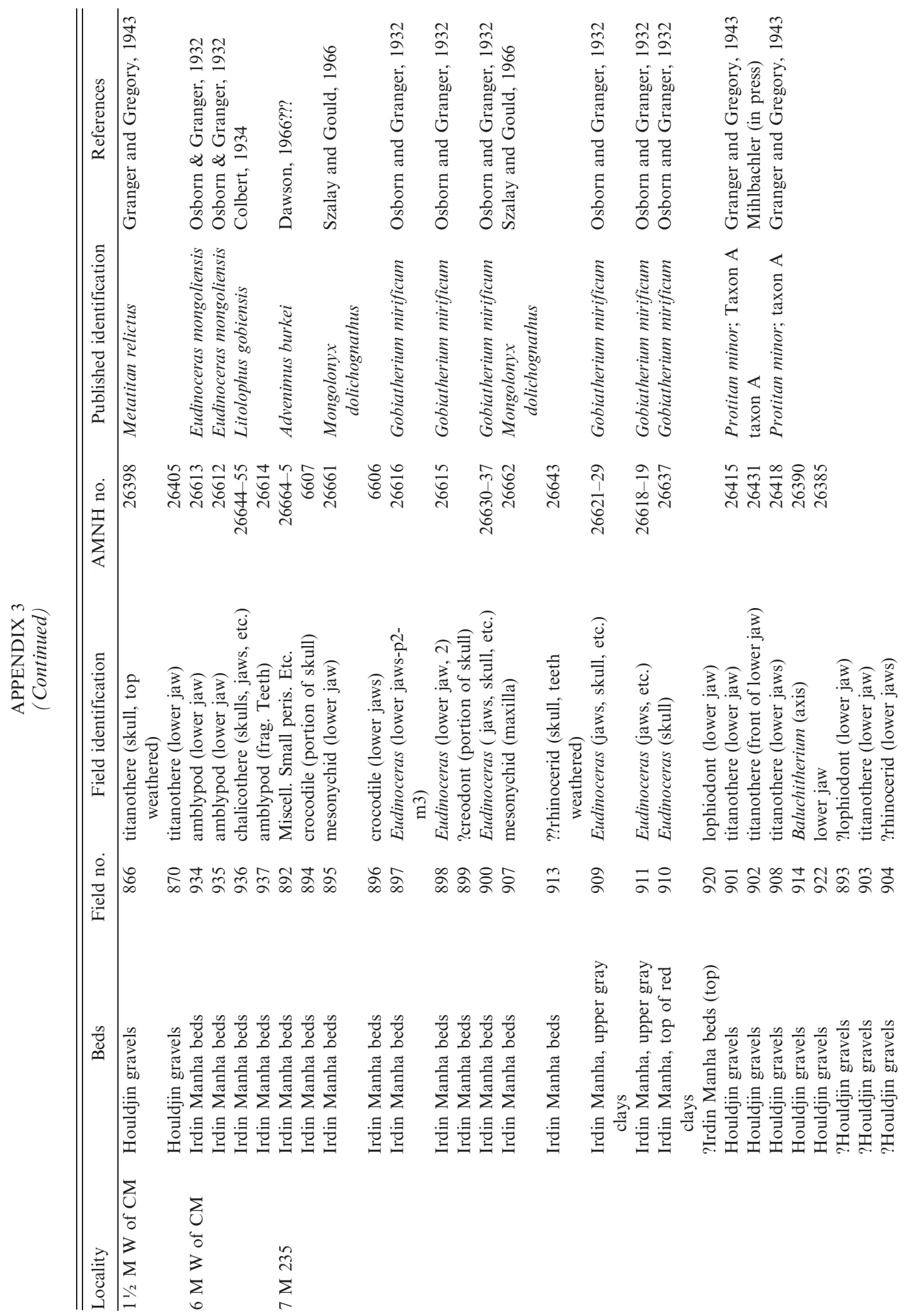




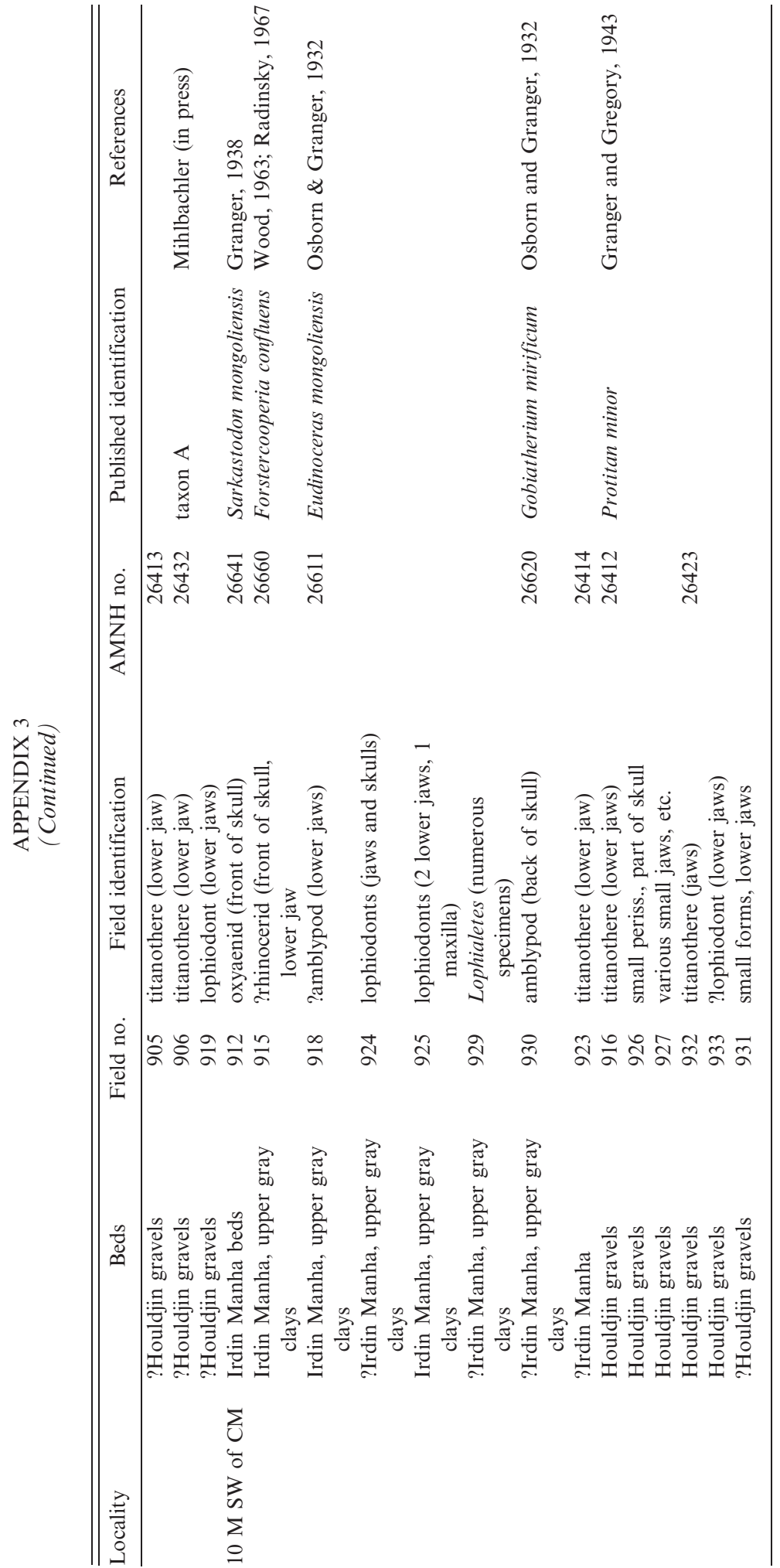


Complete lists of all issues of the Novitates and the Bulletin are available at World Wide Web site http://library.amnh.org/pubs. Inquire about ordering printed copies via e-mail from scipubs@amnh.org or via standard mail from: American Museum of Natural History, Library-Scientific Publications, Central Park West at 79th St., New York, NY 10024. TEL: (212) 769-5545. FAX: (212) 769-5009.

This paper meets the requirements of ANSI/NISO Z39.48-1992 (Permanence of Paper). 